\title{
Two species of Thoracostomopsidae (Nematoda: Enoplida) from Jeju Island, South Korea
}

\author{
Raehyuk Jeong ${ }^{1}$, Alexei V Tchesunov ${ }^{\text {Corresp., }}{ }^{2}$, Wonchoel Lee ${ }^{\text {Corresp. } 1}$ \\ ${ }^{1}$ Department of Life Science, Hanyang University, Seoul, South Korea \\ 2 Department of Invertebrate Zoology, Moscow State University, Moscow, Russia \\ Corresponding Authors: Alexei V Tchesunov, Wonchoel Lee \\ Email address: avtchesunov@yandex.ru, wlee@hanyang.ac.kr
}

During a survey of intertidal zones at beaches on Jeju Island, two species belonging to the family Thoracostomopsidae were discovered. One new species, Enoploides koreanus sp. nov. and one known species, Epacanthion hirsutum Shi \& Xu, 2016 are reported. Along with morphological analysis, mitochondrial cytochrome oxidase c subunit 1 (mtCOI) sequences and 18S rRNA sequences of the species were also obtained and used to check relative p-distance and phylogenetic positions. While most species of Enoploides have long spicules, the new species belongs to a group of Enoploides with short spicules ( $<150 \mu \mathrm{m}$ ). Of the seven species with short spicules, the new species is most closely related to $E$. disparilis Sergeeva, 1974. They both have similar body length, fairly similar sized and shaped spicules with small gubernaculum running parallel to distal end of spicule, and index value of $\mathrm{b}$. The new species can be distinguished from $E$. disparilis by having preanal supplementary organ with short conical tail, while $E$. disparilis lacks pre-anal supplementary organ and has a long conico-cylindrical tail. Along with the description of the new species, the genus Enoploides Ssaveljev, 1912 is bibliographically reviewed and revised. Of 45 species described to date, 27 are now considered valid, 16 species inquirendae due to inadequate descriptions and ambiguity of the material examined, along with two cases of nomen nudum. With this review, we provide an updated diagnosis and list of valid species, a tabular key comparing diagnostic characters of all valid species, and a new complete key to species. One known species, Epacanthion hirsutum Shi \& Xu, 2016, is reported in Korea for the first time. The morphology agrees well with the original description provided by Shi \& Xu (2016). As they had already reviewed the genus at the time of reporting four Epacanthion species, we provide only a description, depiction, and measurements for comparison purposes. 


\section{Two species of Thoracostomopsidae (Nematoda: Enoplida)}

\section{2 from Jeju Island, South Korea}

3

4 Raehyuk Jeong ${ }^{1}$, Alexei V. Tchesunov ${ }^{2}$, Wonchoel Lee ${ }^{1}$

5

$6 \quad{ }^{1}$ Department of Life Science, Hanyang University, Seoul, 04763, South Korea

$7 \quad{ }^{2}$ Department of Invertebrate Zoology, Moscow State University, Moscow, 119991, Russia 8

9 Corresponding Authors:

10 Alexei Tchesunov ${ }^{2}$

11 Department of Invertebrate Zoology, Moscow State University, Moscow, 119991, Russia

12 Email address: avtchesunov@yandex.ru

14 Wonchoel Lee ${ }^{1}$

15 Department of Life Science, Hanyang University, Seoul, 04763, South Korea

16 Email address: wlee@hanyang.ac.kr

17

18 
19

20

21

22

23

24

25

26

27

28

29

30

31

32

33

34

35

36

37

38

39

40

41

42

43

44

45

46

47

48

49

50

51

52

53

54

55

56

57

58

\section{Abstract}

During a survey of intertidal zones at beaches on Jeju Island, two species belonging to the family Thoracostomopsidae were discovered. One new species, Enoploides koreanus sp. nov. and one known species, Epacanthion hirsutum Shi \& Xu, 2016 are reported. Along with morphological analysis, mitochondrial cytochrome oxidase c subunit 1 (mtCOI) sequences and 18S rRNA sequences of the species were also obtained and used to check relative p-distance and phylogenetic positions. While most species of Enoploides have long spicules, the new species belongs to a group of Enoploides with short spicules $(<150 \mu \mathrm{m})$. Of the seven species with short spicules, the new species is most closely related to E. disparilis Sergeeva, 1974. They both have similar body length, fairly similar sized and shaped spicules with small gubernaculum running parallel to distal end of spicule, and index value of $b$. The new species can be distinguished from E. disparilis by having pre-anal supplementary organ with short conical tail, while E. disparilis lacks pre-anal supplementary organ and has a long conico-cylindrical tail. Along with the description of the new species, the genus Enoploides Ssaveljev, 1912 is bibliographically reviewed and revised. Of 45 species described to date, 27 are now considered valid, 16 species inquirendae due to inadequate descriptions and ambiguity of the material examined, along with two cases of nomen nudum. With this review, we provide an updated diagnosis and list of valid species, a tabular key comparing diagnostic characters of all valid species, and a new complete key to species. One known species, Epacanthion hirsutum Shi \& Xu, 2016, is reported in Korea for the first time. The morphology agrees well with the original description provided by Shi \& $\mathrm{Xu}$ (2016). As they had already reviewed the genus at the time of reporting four Epacanthion species, we provide only a description, depiction, and measurements for comparison purposes.

\section{Introduction}

The family Thoracostomopsidae Filipjev, 1927 consists of three subfamilies: Thoracostomopsinae Filipjev, 1927 (2 genera), Trileptiinae Gerlach \& Riemann, 1974 (1 genus), and Enoplolaiminae De Coninck, 1965 (19 genera). They are distinguished by the presence or absence of mandibles (Enoplolaiminae or Trileptiinae respectively) or by the presence of a long and eversible spear (Thoracostomopsinae). Enoploides Ssaweljev, 1912, belonging to Enoplolaiminae, was first erected with type species Enoploides typicus Ssaweljev, 1912 from Russia. The genus is characterized by its high lips with striation; Y-shaped mandibles consisting of two lateral bars converging into one solid bar with a claw-like distal end, curving inwards to the lumen; onchia that are usually shorter than the mandibles; and spicules that are typically long armed with gubernaculum. Multiple revisions and updates of the genus have taken place. The most notable revision was made by Wieser \& Hopper (1967), who questioned validity of many existing species. They argued that classification in this genus is only possible according to male genital armature (gubernaculum), and that all description based only on females and juveniles be considered species inquirenda. Aside from this, species have continuously been transferred from and to closely related genera such as Enoplus Dujardin, 1845; Enoplolaimus de Man, 1893 and Epacanthion Wieser, 1953. Most recently, Smol et al. (2014) listed 28 valid species including 
59

60

61

62

63

64

65

66

67

68

69

70

71

72

73

74

75

76

77

78

79

80

81

82

83

84

85

86

87

88

89

90

91

92

93

94

95

96

97

98

three transferred from Epacanthion by Greenslade \& Nicholas (1991). By the number, it is clear that Smol et al. (2014) considered and applied the list of species inquirendae provided by Wieser \& Hopper (1967), but a full list of species was not supplied. A species list provided by NeMys (Bezerra et al., 2019) still lists some of the species considered invalid by Wieser \& Hopper (1967) as valid species; contains erroneous species such as "Enoploides uniformis Pavljuk, 1984" (discussed further in results); and is missing two of three species transferred from Epacanthion by Greenslade \& Nicholas (1991). Our most recent list of valid species consists of 27 species, including the new species being reported. The last report on Enoploides species dates back to 1993, with a new report on Enoploides stewarti Nicholas, 1993 from a freshwater lake in South Australia. Most species of the genus are from marine habitats with the exception of two freshwater species (Enoploides fluviatilis Micoletzky, 1923 and E. stewarti). Of the 27 valid species, $63 \%$ (17) were initially reported from Europe; $14.8 \%$ (4) from North America; 7.4\% (2) from Asia (including the new species); with 3.7\% (1) each from South America, Africa, Australia and the Arctic.

The aim of this study was to review and revise the genus Enoploides while reporting a new species, Enoploides koreanus sp. nov., found from Jeju Island, Korea. Epacanthion hirsutum originally reported from East China Sea, is also reported in Korea for the first time. Their respective $18 \mathrm{~S}$ rRNA and COI genes were sequenced and used to check p-distances and phylogenetic positions. We also agree that all future description of the genus be from a sound male as first proposed by Wieser \& Hopper (1967).

\section{Materials and Methods}

\section{1) Sampling and morphological study}

Three seemingly natural and undisturbed beaches of Jeju Island were sampled in September 11, 2018. Two sub-samples of sediment from the intertidal zone were obtained qualitatively using a mini-shovel. Of the subsamples, one was fixed in 5\% neutralized formalin solution for morphological analysis and the other was fixed in $70 \%$ ethanol for molecular analysis. Samples were brought back to the laboratory and meiofauna were extracted using the Ludox method (Burgess, 2001). Individual specimens were transferred by hand to a Petri dish filled with $10 \%$ glycerin. Specimen-containing Petri dishes were placed for a day in a dry oven preset to $40^{\circ} \mathrm{C}$ for a day to achieve complete dehydration as described by Seinhorst (1959) with the glycerinethanol method. A single specimen was mounted in a drop of glycerin on a slide glass as conferred in the wax-ring method (Hooper, 1986). Specimens were examined and identified using Olympus BX51 and Leica DM2500 microscopes. For scanning electron microscopy, specimens were removed from the slide glass and placed in a drop of glycerin. Drops of distilled water were added gradually to the drop of glycerin to rehydrate the specimen. Hydrated specimens underwent ethanol series for dehydration $(20 \%, 40 \%, 50 \%, 70 \%, 80 \%, 90 \%, 95 \%$, $100 \%$, for $10 \mathrm{~min}$ each) to be placed in hexamethyldisilazane (HMDS), with slightly altered concentration and duration compared to a method used by Phillips et al. (2016). A pool of HMDS containing the specimen was placed in drying oven to be completely dried overnight. 
99 Dried specimens were mounted on a stub to be sputter-coated, then observed with a COXEM

100

101

102

103

104

105

106

107

108

109

110

111

112

113

114

115

116

117

118

119

120

121

122

123

124

125

126

127

128

129

130

131

132

133

134

135

136

137

138

EM-30 scanning electron microscope.

\section{2) DNA extraction and amplification}

Each specimen of interest was dissected into head, body, and tail. Heads and tails were retained for morphological analysis and made into permanent slides following Hooper's (1986) wax-ring method. The slides were submitted to the National Institute of Biological Resources (NIBR, Korea). Bodies of each specimen were transferred to a well of distilled water for $20 \mathrm{~min}$ to be washed of any remaining ethanol. Washed bodies were moved to individual tubes containing $25 \mu \mathrm{l}$ of worm lysis buffer, prepared prior to extraction following Williams et al. (1992). The tubes were then placed in PCR-thermo cycler (Takara, Japan) preset to $65^{\circ} \mathrm{C}$ for 15 min, $95^{\circ} \mathrm{C}$ for $20 \mathrm{~min}$, and $15^{\circ} \mathrm{C}$ for $2 \mathrm{~min}$. Two gene loci commonly used for marine nematodes were sequenced: mitochondrial cytochrome oxidase $\mathrm{C}$ subunit I (COI) gene and $18 \mathrm{~S}$ small subunit ribosomal rRNA. All genes were amplified using PCR premix (Bioneer Co., Daejeon, Korea) with $5 \mu \mathrm{l}$ DNA template, $15 \mu \mathrm{l}$ distilled water, $1 \mu \mathrm{l}$ of each primer. COI genes were amplified using primer sets (JB3/JB5) amplifying approximately 300 base pairs (bp) as described by Derycke et al., (2010). PCR cycling conditions were: $94^{\circ} \mathrm{C}$ for $5 \mathrm{~min}, 35$ cycles of $\left(94^{\circ} \mathrm{C}\right.$ for $30 \mathrm{~s} ; 50^{\circ} \mathrm{C}$ for $30 \mathrm{~s} ; 72^{\circ} \mathrm{C}$ for $30 \mathrm{~s}$ ), and $72^{\circ} \mathrm{C}$ for $10 \mathrm{~min} .18 \mathrm{~S}$ rRNA was amplified using primer sets (MN18F/22R), amplifying approximately $300 \mathrm{bp}$. PCR cycling conditions were: $95^{\circ} \mathrm{C}$ for 5 $\min , 37$ cycles of $\left(95^{\circ} \mathrm{C}\right.$ for $30 \mathrm{~s}, 56^{\circ} \mathrm{C}$ for $1 \mathrm{~min}, 72^{\circ} \mathrm{C}$ for $\left.1 \min 30 \mathrm{~s}\right)$, followed by $72^{\circ} \mathrm{C}$ for 5 min, as described by Bhadury et al. (2006). Success of amplification was determined by electrophoresis on $1 \%$ agarose gel. If amplification was successful, DNA templates were sent to Macrogene (Korea), to be sequenced on an ABI3730XL sequencer.

\section{3) Molecular data analysis}

Sequenced forward and reverse strands were visually checked for signal quality using FinchTV (ver. 1.4.0). Two strands were aligned with ClustalW (Thompson et al., 1994) implemented into MEGA (ver. 7.0.26) (Kumar et al., 2016) with default parameters. All aligned sequences were confirmed with BLAST search (Altschul et al., 1990) on GenBank to check that the sequences were those of nematodes. Pairwise distances between mtCOI and 18S rRNA sequences were calculated using the K2P model (Kimura, 1980) using MEGA 7. The best fit-model for 18S rRNA datasets were assessed using default parameters implemented in MEGA 7.0 (Kumar et al., 2016). Tamura 3-parameter model (Tamura, 1992) with gamma distribution of rates across sites was found to be optimal and used with MEGA 7.0 to build a maximum likelihood (ML) tree with complete deletion and 1,000 bootstrap repetition. Completed tree was exported to FigTree (ver. 1.4.4) (Rambaut, 2009) and visually modified. Phylogenetic tree was not constructed using the obtained mtCOI sequences, as only few mtCOI sequences of Enoploides were available on GenBank.

\section{4) Bibliographical revision of the genus}

The Bremerhaven Checklist of Aquatic Nematodes by Gerlach \& Riemann (1974) was initially used to collect original descriptions and references. Original erection of the genus, as well as other previous revisions and diagnosis of the genus was checked (Wieser, 1953; Wieser \& 
139 Hopper, 1967; Platt \& Warwick, 1983; Smol et al., 2014). Upon collecting all required

140 references: 1) validity and synonymy of species were examined and determined; 2) a table

141 comparing diagnostic characters of all valid species was compiled; 3 ) locality and distribution of

142 original descriptions were determined; 4) a new complete key to the genus was compiled.

143 5) Nomenclatural Acts

144 The electronic version of this article in Portable Document Format (PDF) will represent a 145 published work according to the International Commission on Zoological Nomenclature (ICZN), 146 and hence the new names contained in the electronic version are effectively published under that 147 Code from the electronic edition alone. This published work and the nomenclatural acts it 148 contains have been registered in ZooBank, the online registration system for the ICZN. The 149 ZooBank LSIDs (Life Science Identifiers) can be resolved and the associated information viewed 150 through any standard web browser by appending the LSID to the prefix http://zoobank.org/. The 151 LSID for this publication is: urn:1sid:zoobank.org:pub:6F60918D-9DE1-4B75-A251-

152 C01E0694D01F. The online version of this work is archived and available from the following 153 digital repositories: PeerJ, PubMed Central and CLOCKSS.

154

155

\section{Abbreviations}

156

157

a: body length / maximum body diameter

158 abd: anal body diameter

159

b: body length / pharynx length

160

c: body length / tail length

161 calc: calculated or measured from published measurements and/or figures

162 cs: cephalic setae

163

c': tail length / anal body diameter

164

ils: inner labial setae

165 ols: outer labial setae

166 scs: subcephalic setae

167

168

169

170

171

172

Order Enoplida Filipjev, 1929

173

Family Thoracostomopsidae Filipjev, 1927

174 Genus Enoploides Ssaveljev, 1912

175

176

Generic diagnosis: (Updated from Wieser, 1953; Wieser \& Hopper, 1967; Platt \& Warwick, 177 1983; Smol et al., 2014) 
178 Enoplolaiminae. Lips high and striated. Buccal cavity with three well-developed solid mandibles

179

180

181

182

183

184

185

186

187

188

189

190

191

192

193

194

195

196

197

198

199

200

201

202

203

204

205

206

207

208

209

210

211

212

213

214

215

216

217

with claw-like anterior; mandible not extremely slender (ratio length/width $<6$ ); Three onchia shorter than the mandibles. Some species showing sexual dimorphism with pilosity either along the body or within the head region. Spicules usually long, some short, armed with either complex s-shaped/simple non s-shaped gubernaculum. Some species with pre-cloacal supplementary organ/papillae or postanal papillae/cuticular element of different form, at varying distances from the cloacal opening. Terminal setae observed at tail tip in some species. Mostly marine, with two freshwater species (E. fluviatilis and E. stewarti).

Type species: Enoploides typicus (Ssaweljev, 1912)

Notes on generic diagnosis: Enoploides can be easily distinguished from other genera such as Enoplolaimus de Man, 1893 and Mesacanthion Filipjev, 1927 by the morphology of its mandibles. Mandibles of Enoploides are described as "solid", signifying that the two lateral bars converge/fuse together to form a single rod for most of its length. This means that from lateral view, the mandible resembles the letter $\mathrm{Y}$, with its distal end of two lateral bars claw-like, curving inward to the lumen (Fig. 1A). Enoploides are sometimes mistaken for Epacanthion Wieser, 1953 (a closely related genus), and vice versa. Mandibles of Epacanthion consist of two lateral bars separated by a thin sheet of cuticles, meaning the space between bars is not solid as in Enoploides (Fig. 1B). This subtle difference is significant enough to separate the two genera, yet easily missed in many diagnoses. Greenslade \& Nicholas (1991) transferred three species previously regarded as members of Epacanthion to the genus Enoploides (E. crassum, E.

filicaudatum and E. incurvatus) after examining their mandibles.

\section{List of valid species}

1. Enoploides amphioxi Filipjev, 1918 (Filipjev, 1918: 92-92, Table 2, 3, fig. 12A-E; one male and several females, Sevastopol, Black Sea, Russia. Stekhoven, 1950: 52, fig. 19A-C; one female, Mediterranean, Villefranche, grey mud, $80 \mathrm{~m}$, deep).

2. Enoploides bisulcus Wieser \& Hopper, 1967 (Wieser \& Hopper, 1967: 252-253, fig. 1i, 10A-D; description based on several males and females, Key Biscayne, Florida, USA, shallow water close to submerged patch, fine sand and debris).

3. Enoploides brunettii Gerlach, 1953 (Gerlach, 1953: 527-529, Abb. 4, fig. 4A-E; description based on two males and one female, Mediterranean. Warwick, 1971: 444-451; Exe estuary, England).

4. Enoploides caspersi Riemann, 1966 (Riemann, 1966: 186-188, Abb. 49A-F; description based on three male and one female, Elbe estuary, North Sea, Germany).

5. Enoploides cephalophorus (Ditlevsen, 1918) Filipjev, 1927 [Ditlevsen, 1918: 207-208, Pl. 14, fig. 1, 5, 6, Pl. 15, fig. 1; (=Enoplolaimus cephalophorus), description based on several males and females, Limfjord, off Snoghøj, off Hellebæk, Denmark. Filipjev, 1927: 142; (as

Peer) reviewing PDF | (2019:10:41933:3:0:NEW 23 Mar 2020) 
218

219

220

221

222

223

224

225

226

227

228

229

230

231

232

233

234

235

236

237

238

239

240

241

242

243

244

245

246

247

248

249

250

251

252

253

254

255

256

257

Enoploides cephalophorus), several males and females, Kara Sea, yellow sand, $20 \mathrm{~m}$ deep. Allgén, 1946: 5; (as Enoplolaimus (Enoploides) cephalophorus Ditlevsen), several males and females, Norway].

6. Enoploides cirrhatus Filipjev, 1918 [Filipjev, 1918: 101-103, Table 3, fig. 15A-D; description based on one male, Shimit Bay, Sevastopol, Black Sea, Russia, saccocirrous sand. Allgén, 1940: 263, fig. 1A-C; (as Enoplolaimus (Enoploides) cirrhatus Filipjev), Norway].

7. Enoploides crassum (Ditlevsen, 1926) Greenslade \& Nicholas, 1991 [Ditlevsen, 1926: 39-40, Pl. 15, figs. 3, 6, 7, 8; (=Enoplolaimus crassus), description based on one male and several females, Iceland, Faroe Island, Jan Mayen. Wieser, 1953: 79; (=Epacanthion crassus), transfers the species to the genus Epacanthion. Greenslade \& Nicholas, 1991: 1041; (=Enoploides crassus), transfers the species to the genus Enoploides, explaining that the original drawing and description of the mandible does not agree with character of Epacanthion. Smol et al., 2014: 202; lapsus crassum].

8. Enoploides delamarei Boucher, 1977 (Boucher, 1977: 746-748, fig. 6A-G; description based on three males, four females and three juveniles, Pierre Noire (Western Channel), France, infralittoral fine sands).

9. Enoploides disparilis Sergeeva, 1974 (Sergeeva, 1974: 122, fig. 2A-B; description based on one male, Black Sea, fine sand, 10m deep).

10. Enoploides fluviatilis Micoletzky, 1923 [Micoletzky, 1923: 13-15, fig. 1A-C; description based on four males, five females and three juveniles, Volga river (freshwater), Russia. Also from brackish-water Caspian Sea (ca 13\%) - data of Tchesunov, A.V.].

11. Enoploides gryphus Wieser \& Hopper, 1967 (Wieser \& Hopper, 1967: 235, P1. 3, fig. 11C, P1. 5, fig. 11A-B; description based on several males, Virginia Key, Florida, USA).

12. Enoploides harpax Wieser, 1959 (Wieser, 1959: 21-22, fig. 16A-C; description based on one male and one female, Alki Point, Golden Gardens, Richmond Beach, Seattle Washington, USA).

13. Enoploides hirsutus Filipjev, 1918 (Filipjev, 1918: 97-100, Table 3, fig. 13; description based on one male, Sevasotopol, Black Sea, Russia, mud).

14. Enoploides incurvatus (Ditlevsen, 1926) Greenslade \& Nicholas, 1991 [Ditlevsen, 1926: 37, Pl. 14, figs. 4, 5, 8, 9, Pl. 15, fig. 5; (=Enoplolaimus incurvatus), description based on male and female, Hanstholm, Denmark. Schuurmans Stekhoven, 1946: 44, fig. 13 A-O; (=Enoploides incurvatus), two males, two females and one juvenile, Langesundsfjord, Skageraks, Sweden, rocky bottom, 150-200 m deep. Wieser, 1953: 79; (=Epacanthion incurvatus). Greenslade \& Nicholas, 1991: 1034; mentioned that Schuurmans Stekhoven's (1946) redescription was of different species, renames the species Epacanthion stekhoveni, on account of a space between the mandibular columns].

15. Enoploides labiatus (Bütschli, 1874) Filipjev, 1918 [Bütschli, 1874: 41, fig. 36A-B; (=Enoplus labiatus), description based on female, North Sea. Filipjev, 1918: 91; (=Enoploides labiatus). Wieser, 1953: 87; the species is considered as Enoploides, but also 
272

273

274

275

276

277

278

279

280

281

282

283

284

285

286

287

288

289

290

291

292

293

294

295

296

297

synonymous with E. spiculohamatus Schulz, 1932. Wieser \& Hopper, 1967: 251; mentions the species as a doubtful species and adds that synonymy of E. labiatus and $E$. spiculohamatus cannot be proven and thus should be abandoned. Bouwman, 1981: 63, fig. 26; (=Enoploides cf labiatus Bütschli, 1874), 6 males, 10 females and dozens of juveniles, the Ems Estuary, mentions that there is high probability that E. labiatus is synonymous with E. spiculohamatus].

16. Enoploides labrostriatus (Southern, 1914) Filipjev, 1921 [Southern, 1914: 53-54, P1. 8, fig. 24A-F; (=Enoplus labrostriatus), description based on males, females and juveniles, Clew Bay, Ireland, sand and shells, 44m deep (converted from fathoms). Filipjev, 1921: 565-567; transfers the species to the genus Enoploides. Filipjev, 1927: 141; acknowledges the species as the genus Enoploides].

17. Enoploides longispiculosus Vitiello, 1967 (Vitiello, 1967: 407-410, fig. 3A-G; description based on two males, one female and two juveniles, English Channel).

18. Enoploides mandibularis Coles, 1977 (Coles, 1977: 25-27, fig. 8A-C; description based on seven males and ten females; Saldanha Bay, False Bay, South Africa. The mandible is described as "solid" and with broad central expansion on the side facing the buccal cavity. The original figures on the mandibles raise some questions regarding its placement in the genus. Types will have to be examined for further determination).

19. Enoploides polysetosus Jensen, 1986 (Jensen, 1986: 93-94, fig. 1A-G; description based on seven males, seven females and thirteen juveniles, East Flower Garden, NW Gulf of Mexico).

20. Enoploides ponticus Sergeeva, 1974 (Sergeeva, 1974: 122, fig. 3A-B; description based on one male, Black Sea, silt, $82 \mathrm{~m}$ deep).

21. Enoploides rimiformis Pavljuk, 1984 [Pavljuk, 1984: 1145-1146, fig. 1D-Z (in Russian alphabet); description based on males and females. Sea of Japan (East Sea), sand].

22. Enoploides spiculohamatus Schulz, 1932 (Schulz, 1932: 341-344, fig. 5A-K; description based on males and female, Kiel Bay. Benwell, 1981: 177-181, fig. 1A-D; two males and two juveniles examined, Scotland, states that Bresslau \& Stekhoven (1940) may be $E$. spiculohamatus, but the description is poor; also states that Stekhoven (1935) is not $E$. spiculomahatus, but lacks details to consider it a new species).

23. Enoploides stewarti Nicholas, 1993 (Nicholas, 1993: 167-170, fig. 2E-F, 3A-E; description based on several males and females, Lake Alexandrina, South Australia, sand at water edge of freshwater).

24. Enoploides typicus Ssaweljev, 1912 (Ssaweljev, 1912: 115; description based on one male, no depiction, Kolafjord, Russia, mud, 70-80m deep).

25. Enoploides tyrrhenicus Brunetti, 1949 (Brunetti, 1949: 42-44; Mediterranean. Gerlach, 1953: 526-527, fig. 3A-E; three males, Mediterranean).

26. Enoploides vectis Gerlach, 1957 [Gerlach, 1957: 426, fig. 4C-G; (=Enoploides brunettii var. vectis var. n.), description based on a male, Rio de Janeiro, Brazil, middle sand. Wieser \& Hopper, 1967: 252; raised to species level]. 
298

299

300

301

302

303

304

305

306

307

308

309

310

311

312

313

314

315

316

317

318

319

320

321

322

323

324

325

326

327

328

329

330

331

332

333

334

335

336

337

\section{Species inquirendae}

1. Enoploides brattstroemi Wieser, 1953 (Wieser, 1953: 88-89, fig. 47A-B; description based on two juveniles, Gulf of Corcovado and Boca del Guafo, Chile, littoral and sublittoral, sheltered algae and coarse bottom, $25 \mathrm{~m}$ deep, lapsus brattströmi. Wieser \& Hopper, 1967: 251; argues that classification within this genus is only possible using the male genital armature, and classifies any existing descriptions based on only juveniles and females as species inquirendae).

2. Enoploides brevis Filipjev, 1918 (Filipjev, 1918: 100-101, Table 3, fig. 14; description based on immature female, Sevastopol, Black Sea, Russia. Wieser \& Hopper, 1967: 251; argues that classification within this genus is only possible using the male genital armature, and classifies any existing descriptions based on only juveniles and females as species inquirendae).

3. Enoploides filicaudatum (Mawson, 1956) Greenslade \& Nicholas, 1991 [Mawson, 1956: 64, fig. 27A-B; (=Epacanthion Filicaudatum), description based on two juveniles, Antarctic. Greenslad \& Nicholas, 1991: 1041, fig. 6; transfers the species to the genus Enoploides after examining a juvenile kept in South Australian Museum collection (SAMA V3267), which they designated as lectotype. According to them, the mandibles are distinctly solid with mandibular rods joined medially, fitting of mandibles found in the genus Enoploides. This species is placed as species inquirenda due to the following reasons: 1) The original description was based on two juveniles, which Greenslade \& Nicholas (1991) later could only locate one. We agree with Wieser \& Hopper (1967) whom insisted descriptions based on only females and juveniles are insufficient to distinguish between species; 2) While Greenslade \& Nicholas (1991) confirmed that the mandibles of this species resemble ones found in the genus Enoploides, it is still difficult to distinguish it from other species within the genus. For instance, its species defining characteristic as according to Mawson (1956) is for its tail shape. This characteristic alone is too ambiguous to define a species].

4. Enoploides italicus (Steiner, 1921) Filipjev, 1918 [Steiner, 1921: 54, fig. A ${ }^{1}$; (=Enoplolaimus italicus), no locality, no measurements. Filipjev, 1927: 141; (=Enoploides italicus). Wieser, 1953: 88; mentions the species being doubtful, reasoning original description only being provided with a figure of a head with 12 setae without description].

5. Enoploides kerguelensis Mawson, 1958 (Mawson, 1958: 345, fig. 27A-C; description based on one female and three juveniles, Kerguelen Island, Antarctica. Wieser \& Hopper, 1967: 252; argues that classification within this genus is only possible using the male genital armature, and classifies any existing descriptions based on only juveniles and females as species inquirendae).

6. Enoploides longicaudatus Wieser, 1953 (Wieser, 1953: 91, fig. 51A-B; description based on two juveniles, Golfo de Ancud, Chile, coarse sand, small stones and a few boulders, 
338

339

340

341

342

343

344

345

346

347

348

349

350

351

352

353

354

355

356

357

358

359

360

361

362

363

364

365

366

367

368

369

370

371

372

373

374

375

376

377 much detritus, 30-40 m deep. Wieser \& Hopper, 1967: 252; argues that classification within this genus is only possible using the male genital armature, and classifies any existing descriptions based on only juveniles and females as species inquirendae).

7. Enoploides longisetosus Schuurmans Stekhoven, 1943 (Schuurmans Stekhoven, 1943: 338-339, fig. 10A-B; description based on a juvenile, Chile. Wieser, 1953: 88; mentions that the species is doubtful because only one juvenile is known and cervical and body setae are very long. Based on the fact that the description is based on one juvenile, the species is considered species inquirenda).

8. Enoploides macrochaetus (Allgén, 1929) De Coninck \& Schuurmans Stekhoven, 1933 (species inquirenda) [Allgén, 1929: 15-16, fig. 5A-B; (=Enoplolaimus macrochaetus), description based on a juvenile, Skagerrak, Sweden. Allgén, 1953: 555; transfers the species to the genus Enoploides. De Coninck \& Schuurmans Stekhoven, 1933: 39; labels it a doubtful species due to the original description lacking sufficient figures].

9. Enoploides oligochaetus Mawson, 1956 (Mawson, 1956: 67-68, fig. 31-33; description based on three juvenile females, Antarctica, no mud, $163 \mathrm{~m}$ deep. Wieser \& Hopper, 1967: 252; argues that classification within this genus is only possible using the male genital armature, and classifies any existing descriptions based on only juveniles and females as species inquirendae, lapsus oligotricha).

10. Enoploides paralabiatus Wieser, 1953 (Wieser, 1953: 89, fig. 49A-C; description based on four juveniles and three females, Seno Reloncavi, Chile, sand and mud with terrestrial plant detritus. Wieser \& Hopper, 1967: 252; argues that classification within this genus is only possible using the male genital armature, and classifies any existing descriptions based on only juveniles and females as species inquirendae).

11. Enoploides pterognathus Mawson, 1956 (Mawson, 1956; 68-69, fig. 32A-B; description based on juvenile females, Antarctica. Wieser \& Hopper, 1967: 252; argues that classification within this genus is only possible using the male genital armature, and classifies any existing descriptions based on only juveniles and females as species inquirendae).

12. Enoploides reductus Wieser, 1953 (Wieser, 1953: 91, fig. 50A-B; description based on one juvenile, Golfo Corcovado and Boca del Guafo, Chile, coarse sand with some stones, 25 m deep. Wieser \& Hopper, 1967: 252; argues that classification within this genus is only possible using the male genital armature, and classifies any existing descriptions based on only juveniles and females as species inquirendae).

13. Enoploides sabulicola (Allgen, 1933) Wieser, 1953 [Allgen, 1933: 24-25, fig. 8A-B; (=Enoplolaimus sabulicola), description based on one juvenile, Norway. Wieser, 1953: 88; transfers the species to the genus Enoploides, but lists it as a doubtful species, likely due to the original description being based on a single juvenile and insufficient description].

14. Enoploides suecicus De Coninck \& Stekhoven, 1933 [Allgén, 1929: 13-14, fig. 3A-B; (=Enoplolaimus savaljevi), description based on one juvenile, Sweden. De Coninck \& 
378

379

380

381

382

383

384

385

386

387

388

389

390

391

392

393

394

395

396

397

398

399

400

401

402

403

404

405

406

407

408

409

410

411

412

413

414

415

416

417

Stekhoven, 1933: 25; transfers the species to the genus Enoploides. Wieser, 1953: 88; lists Enoplolaimus saveljevi as synonymous to E. balticus Stekhoven, 1935, while listing $E$. balticus as a doubtful species. Also mentions they are most likely juveniles of $E$. labiatus. De Coninck \& Stekhoven, 1933: 25; nomen novum Enoploides suecicus nom. nov. for Enoplolaimus saveljevi].

15. Enoploides tridentatus Ssaweljev, 1912 (Ssaweljev, 1912: 116; description based on one female, no depiction, Kolafjord, Russia. Wieser \& Hopper, 1967: 252; argues that classification within this genus is only possible using the male genital armature, and classifies any existing descriptions based on only juveniles and females as species inquirendae).

\section{Nomen nudum}

1. Enoploides tyrannis Bussau, 1993 (nomen nudum) (Bussau, 1993: 465-469, fig. 198AC, 199A-D; description based on one male and two females. Bussau, 1993 is considered nomen nudum as it does not conform to Article 13 of ICZN (1999).

2. Enoploides uniformis Pavljuk, 1984 [Pavljuk, 1984: 1145-1146, fig. 1D-Z (in Russian alphabet); (=Enoploides rimiformis), description based on males and females. Sea of Japan (East Sea), sand. This species name is an accepted name on NeMys, however, Pavljuk, 1984 does not include a description of a species with such name. It is likely a genuine mistake confusing the name of rimiformis as uniformis].

\section{Enoploides koreanus sp. nov.}

Figs. 1A, 2, 3, Table 1

urn:1sid:zoobank.org:act:87CC02F7-3A2E-4137-84E5-C8E7A97DA6D2

Description: Males (Fig. 2; holotype $n=1$, paratype $n=2$ ). Cuticle smooth above cephalic capsule, strongly striated below cephalic capsule until tail tip (Fig. 4A, B). Three lips high with its border striated heavily with grooves, each lip with two inner labial setae. Six inner labial setae, long and thin (11 $\mu \mathrm{m}$ long), at base of lips in one crown. Six longer outer labial setae (43 $\mu \mathrm{m}$ long) and four shorter cephalic setae (15 $\mu \mathrm{m}$ long) in one crown, situated at anterior portion of cephalic capsule. 20 subcephalic/cervical setae immediately after, some near second crown of setae near outer labial and cephalic setae, some near region of cephalic capsule end, in random lengths, some short, some as long as cephalic setae (Fig. 4A). Buccal cavity short and funnel shaped, wide at the anterior end, narrowing gradually towards the base. Buccal cavity armed with three equally sized and shaped "solid" mandibles and teeth. Mandible Y-shaped, two lateral bars converging into one solid bar, with distal end of each lateral bars claw-like, curving inwards to the lumen. Three onchia of equal size, posterior to each base of mandibles. Amphid not observed. Somatic setae irregularly scattered along the cervical region, in random lengths. Pilosity denser from level of buccal cavity until the nerve ring region. Pharynx long with grooves 
418 and sinuous external contours. Cardia inverse triangular shaped seemingly embedded into the 419 intestine. Somatic setae sparsely distributed along the body in singles until tail region.

420 Metanemes not observed. Testes paired and opposed, anterior testis slightly right of the intestine 421 and posterior testis also to right of the intestine. Precloacal supplementary organ, $8 \mu \mathrm{m}$ long, 82 $422 \mu \mathrm{m}$ above cloacal opening, roughly 2.6 anal body diameters above the anus. Spicules paired, 423 simple, thin and curved at an obtuse angle, proximal end with a knob (more distinct in some

424

425

426

427

428

429

430

431

432

433

434

435

436

437

438

439

440

441

442

443

444

445

446

447

448

449

450

451

452

453

454

455

456

457 specimens than others) and distal end blunt and rounded. Spicule width equivalent throughout its length. Gubernaculum simple, rod-like shape, running parallel to distal half of spicule from level of spicule curvature to its distal end. Distal end with slightly rounded head (Fig. 4C). Tail region with some somatic setae in singles with no patterns observed. Tail conical, inconspicuously cylindrical at distal end. Caudal glands just below distal end of the spicules, at level of anus, running until a well-developed spinneret. Several caudal setae observed (Fig. 4B) along the tail with no terminal setae present at tail tip.

Female (Fig. 3; allotype $n=1$, paratype $n=5$ ). Female generally longer and larger in size. Short sub-cephalic setae below outer labial and cephalic setae (Fig. 4D). Cervical setae in singles and less frequent compared to male at posterior end of cephalic capsule. Reproductive system didelphic-amphidelphic, both ovaries reflexed, positioned left of intestine (Fig. 3C). Tail region with some caudal setae in singles with no visible patterns. No terminal setae observed at tail tip.

Type locality: Intertidal zone at coast of Shinyang Seopjikoji Beach (West), Jeju Island, South Korea (3326'05'N $126^{\circ} 55^{\prime} 15^{\prime \prime}$ ), in sandy beach with some algae, collected 11 September 2018.

Materials examined: All specimens deposited in the National Institute of Biological Resources (South Korea). Holotype $1 \delta^{\widehat{O}}$ (NIBRIV0000858255) on one slide, Allotype $1 q$

(NIBRIV0000858256) on one slide, Paratypes $1 \overbrace{}^{\lambda}, 4 q \circ$ all on separate slide (NIBRIV0000858257-NIBRIV0000858261), $1 \delta$ and 290 dried, mounted on two separate stubs, each sex on separate stubs and coated with gold for SEM (NIBRIV0000858262, NIBRIV0000858263).

Additional materials examined: All specimens deposited in the National Institute of Biological Resources (South Korea). 19 , and 3 juveniles all on separate slide but with only head and tails retained, with segment of body used for molecular analysis. (NIBRIV0000858264NIBRIV0000858267).

Diagnosis: Enoploides. Male. Body length 1851-2307 $\mu \mathrm{m}$. Cuticle finely striated along the body, smooth only in cephalic capsule region. Six inner labial setae 11-19 $\mu \mathrm{m}$. Six longer outer labial setae 30-48 $\mu \mathrm{m}$, four shorter cephalic setae 11-20 $\mu \mathrm{m}$ long sharing one crown. Many subcephalic and cervical setae in head region in case of males, less dense in case of females. Buccal cavity 18-30 $\mu \mathrm{m}$ long. Males with testis paired and opposed. Spicule short (34-39 $\mu \mathrm{m})$, 
458 thin, curved at obtuse angle, its width equal throughout the length. Distal end rounded with knob

459 on proximal end. Gubernaculum simple rod-shaped, running parallel to distal end of spicules.

460 Distal end with subtle round head. Precloacal supplementary organ present. Tail conical,

461 inconspicuously cylindrical at distal end. $\mathrm{a}=58.5-67.1, \mathrm{~b}=4.1-4.4, \mathrm{c}=16.2-18.8, \mathrm{c}^{\prime}=3.7-4.2$.

462

463

464

Differential diagnosis: This diverse genus consisting of 27 valid species can be divided into two groups by the length of their spicules: 1) a group with short spicules $(<150 \mu \mathrm{m}) ; 2)$ a group with

465

466

467

468

469

470

471

472

473

474

475

476

477

478

479

480

481

482

483

484

485

486

487

488

489

490

491

492

493

494

495

496

497

long spicules $(>150 \mu \mathrm{m})$. Instead of comparing just the spicule length, it would have been ideal to separate the group by spicule length/abd. Many species unfortunately lack measurement of anal body diameter in their description, making this a difficult task. Total of seven species have spicules shorter than $150 \mu \mathrm{m}$ : E. caspersi, E. cirrhatus, E. disparilis, E. fluviatilis, E. stewarti, E. tyrrhenicus, and E. koreanus sp. nov. When Nicholas (1993) first acknowledged this group and created a key for Enoploides with short spicules, he included E. polysetosus, but even then it was distinguished for having the longest spicules in the group. We defined this group to consist of those bearing spicules shorter than $150 \mu \mathrm{m}$. E. polysetosus is therefore no longer considered to have short spicules. Species such as E. caspersi and E. tyrrhenicus can easily be distinguished from the other by the former's unique post-anal organ and the latter's complex gubernaculum. Of the seven species, the new species is most closely related to $E$. disparilis in terms of general morphology: 1) they both have simple and short spicules (34-39 $\mu \mathrm{m}$ vs. $35 \mu \mathrm{m})$ with a knob on its proximal end; 2$)$ they both have simple and short gubernaculum (12 $\mu \mathrm{m}$ vs. $19 \mu \mathrm{m})$ parallel to distal end of the spicule; and 3) they share similar body lengths $(2107-2307 \mu \mathrm{m}$ vs. $2250 \mu \mathrm{m})$ and index value of $b$ (4.1-4.4 vs. 4.4). They can be differentiated from one another by the following characteristics: 1 ) the new species has a pre-anal supplementary organ, while $E$. disparilis does not; 2) the new species has a shorter conical tail (121-130 $\mu \mathrm{m})$, while $E$. disparilis has a longer conico-cylindrical tail $(254 \mu \mathrm{m}) ; 3)$ the new species and $E$. disparilis have different index values of a (58.5-67.1 vs. 44.7$)$ and c (16.2-18.8 vs. 9.8). Another species similar to the new species is E. cirrhatus. which also bears a small spicule with a knobbed proximal end and similarly shaped gubernaculum (adjacent to the spicules, small and curved at upper end). Aside from those characteristics, the new species differ from E. cirrhatus in the body lengths $(2107-2307 \mu \mathrm{m}$ vs. $4350 \mu \mathrm{m})$, index values ( $\mathrm{a}=58.5-67.1$ vs. 26 ; $\mathrm{b}=4.1-4.4$ vs. 5.25$)$ all differ greatly, and E. cirrhatus does not have a pre-anal supplementary organ, but bear seven pairs of pre-anal papillae instead.

Group of species with long spicules ( $>150 \mu \mathrm{m})$ can be further divided into subgroups by the morphology of the gubernaculum: 1) S-shaped gubernaculum; 2) complex gubernaculum; 3) gubernacula that are short, simple, small, plated, arcuate, or weak. The term "S-shaped" has been used by several authors, including Filipjev (1918), Wieser \& Hopper (1967), and Pavljuk (1984), to describe certain shapes of the gubernaculum. Wieser \& Hopper (1967) conveniently grouped species with this S-shaped gubernaculum (E. cephalophorus, E. gryphus, E. spiculohamatus, E. amphioxi, E. labrostriatus and E. bisulcus) and provided a figure showing different gubernacula of several species within the genus. The S-shape can be extremely general and almost any shape

Peer) reviewing PDF | (2019:10:41933:3:0:NEW 23 Mar 2020) 
498 can be regarded as S-shapes given the curving nature of gubernaculum's contours. For instance, 499 gubernaculum of E. spiculohamatus was considered S-shaped by Wieser \& Hopper (1967), while 500 gubernaculum of E. vectis was not. Wieser \& Hopper (1967) even referred to this group as "more 501 or less S-shaped" confirming its ambiguous nature. To reduce ambiguity, any gubernaculum 502 described as complex in the original description or consisting of multiple parts is not considered 503 S-shaped here. There is certainly some uniformity of morphology of these "complex" 504 gubernacula, which consist of multiple parts, bluntly shaped, anterior to the spicules. This 505 removes E. spiculohamatus from the S-shaped group initially assigned by Wieser \& Hopper 506 (1967), as its gubernaculum consists of multiple parts and more closely resembles other 507 complex-gubernaculum bearing species such as E. brunettii, E. labiatus, E. longispiculosus, and 508 E. vectis. Refer to Table 2 for comparison of diagnostic morphological characters and 509 gubernaculum type of all valid Enoploides species.

510

511 Etymology: The species name refers to its occurrence in Korea.

512

513 Key to all valid species of the genus Enoploides

514

515 1. Spicules less than $150 \mu \mathrm{m}$ long... 2

516 -Spicules more than $150 \mu \mathrm{m}$ long... 7

517 2. Presence of a prominent post-anal supplementary organ ... E. caspersi

518 -Absence of a prominent post-anal supplementary organ ... 3

519 3. Pre-anal supplementary organ absent ... 4

520 -One pre-anal supplementary organ present ... 5

521 -Seven to eight pre-anal supplementary papillae in midline ... E. cirrhatus

5224 4. index $\sim \sim 9$, spicules $\sim 35 \mu \mathrm{m}$ long and gubernaculum without apophysis ... E. disparilis

523 -index $\mathrm{c} \sim 12-16$, spicules $\sim 90 \mu \mathrm{m}$ long and gubernaculum with weak apophysis... E. tyrrhenicus

524 5. Tail shorter than $100 \mu \mathrm{m}$ with two post-anal papillae ... E. fluviatilis

525 -Tail longer than $100 \mu \mathrm{m} \ldots 6$

526 6. Spicule $\sim 100 \mu \mathrm{m}$ long with plate-like gubernaculum with weak apophysis and three terminal 527 setae at tail tip ... E. stewarti

528 -Spicule $\sim 30-40 \mu \mathrm{m}$ long with rod-like gubernaculum with a rounded head at distal end and no 529 terminal setae at tail tip ... E. koreanus sp. nov.

530 7. Gubernaculum S-shaped ... 16

531 -Gubernaculum not S-shaped ... 8

532 8. Gubernaculum complex with multiple parts ...9

533 -Gubernaculum short/small, weak, arcuate, plate ... 12

534 9. Pre-anal supplementary organ less than 1 abd away from cloacal opening ... E. vectis

535 -Pre-anal supplementary organ 1.5-1.7 abd away from cloacal opening ... E. spiculohamatus

536 -Pre-anal supplementary organ more than 2 abd away from cloacal opening . . 10

537 10. Spicule length less than $200(<4$ abd $)$... E. brunettii 
538 -Spicule length greater than 200 ( $>4$ abd) $\ldots 11$

539 11. Post-anal cuticular element characteristically S-curved ... E. labiatus

540 -Post-anal cuticular element not s-curved ... E. longispiculosus

541 12. Cephalic setae shorter than $10 \mu \mathrm{m}$ and buccal cavity extremely short $(9 \mu \mathrm{m}) \ldots$ E. typicus

542 -Cephalic setae longer than $20 \mu \mathrm{m}$ and buccal cavity average ... 13

543 13. Mandible with unique broad central expansion facing the buccal cavity ... E. mandibularis

544 -Mandible generic in characteristic to the genus ... 14

545 14. Proximal end of spicule funnel shaped ... E. incurvatus

546 -Proximal end of spicule not funnel shaped, normally curved ... 15

547 15. Gubernaculum embracing the distal end of spicule, forming a short plate on each side ... $E$.

548 crassum

549 -Gubernaculum triangular, unpaired, flat, covering the spicules above and below ... E. hirsutum

550 -Gubernaculum arcuate with wide distal end and narrow and curved proximal end ... E ponticus

551 16. Head globular ... E. cephalophorus

552 -Head non-globular ... 17

553 17. Presence of cracks on mandibles ... E. rimiformis

554 -Absence of cracks on mandibles ... 18

555 18. Dorsal tooth missing ... E. delamarei

556 -Dorsal tooth present ... 19

557 19. Distal end of spicule with mobile spine ... E. amphioxi

558 -Distal end of spicule without mobile spine ... 20

559 20. Gubernaculum with characteristic ventral knob ... E. gryphus

560 -Gubernaculum without characteristic ventral knob ... 21

561 21. Spicule with diagonal reinforcement ... 22

562 -Spicule without diagonal reinforcement ... 23

563 22. Spicule longer than $400 \mu \mathrm{m}$... E. bisulcus

564 -Spicule shorter than $300 \mu \mathrm{m}$... E. harpax

565 23. Spicule $\sim 490 \mu \mathrm{m}$ long and smooth, proximal end funnel shaped and distal end slightly

566 expanded and pointed, index $\mathrm{c} \sim 20 \ldots$ E. labrostriatus

567 -Spicule $\sim 160-170 \mu \mathrm{m}$ long, almost straight, index c $\sim 11-16 \ldots$ E. polysetosus

568

569 Order Enoplida Filipjev, 1929

570 Family Thoracostomopsidae Filipjev, 1927

571 Subfamily Enoplolaiminae de Coninck, 1965

572 Genus Epacanthion Wieser, 1953

573 Epacanthion hirsutum Shi \& Xu, 2016

574 Fig. 5, Table 3

575

576 Description: Male (Fig. 5; holotype $\mathrm{n}=1$ ). Cuticle smooth. Lips high with heavy striation and

577 grooves, each lip bearing two inner labial setae. Six inner labial setae, fairly long and thin at base 
578 of lips in one crown. Six longer outer labial setae and four shorter cephalic setae in one crown.

579 Cervical setae scattered randomly at posterior end of cephalic capsule, as long as cephalic setae.

580 Buccal cavity funnel shaped, wide at the anterior end, gradually narrowing towards the base.

581 Buccal cavity armed with three equally sized and shaped mandibles and teeth, respectively.

582 Mandibles with two lateral bars diverging away from one another distally. Distal end of each

583 lateral bars "claw-like", curving towards the lumen like hooks. Mandibles widening near the

584 base, each armed with fairly weak, narrow looking onchia. Mandibular columns divided by a

585 sheet of cuticle. Pharyngeal glands not readily visible. Pharynx fairly long and muscular, its

586 width consistent throughout its length, except the swollen anterior end. Fairly long somatic setae

587 in singles, randomly distributed along the head. Pilosity intense until level of nerve ring, scarcer

588 throughout. A little below the level of nerve ring, a ring of densely arranged cervical setae.

589 Cardia inverse triangular, seemingly embedded in the intestine. Testes paired and opposed, both

590 ends positioned left of intestine. Spicules slightly curved with small gubernaculum at distal end

591 of spicules. No precloacal supplementary organ observed. Caudal glands after cloacal opening,

592 well-developed. Tail conical-cylindrical, two long sub-terminal setae observed and two terminal

593 setae at tail tip.

594

595 Type species: Epacanthion buetschlii (Southern, 1914) (28 valid species) (Refer to Shi \& Xu, 596 2016)

597

598 Locality: Intertidal zone at coast of Shinyang Seopjikoji Beach (East), Jeju Island, South Korea

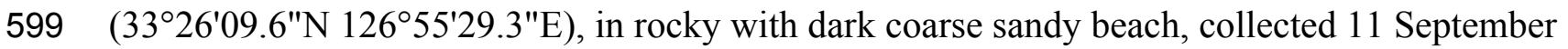
6002018.

601

602 Materials examined: All specimens deposited in the National Institute of Biological Resources 603 (South Korea). 10 (NIBRIV0000858270).

604

605

Additional materials examined: All specimens deposited in the National Institute of Biological

606 Resources (South Korea). 1웅 and 1 juvenile all on a separate slide but with only head and tails

607 retained, with segment of body used for molecular analysis. (NIBRIV0000858271,

608 NIBRIV0000858272).

609

610 Remarks: The morphology agrees well to the description provided by the original authors, Shi

$611 \& \mathrm{Xu}$ (2016). Mandibles clearly resemble those seen in Epacanthion species, consisting of two

612 lateral bars (parallel to one another and the space in between not solid) separated by a thin sheet

613 of cuticle. Its distinguishing characteristic, a single row or ring of densely arranged setae below

614 the level of the nerve ring is quite distinct. All measurements are also within the range of the

615 original (Table 3$)$

616

617 Molecular analysis 
618 Mitochondrial cytochrome oxidase C subunit 1 (mtCOI)

619 We successfully amplified and sequenced DNA of four Enoploides koreanus sp. nov. and two

620 Epacanthion hirsutum. Despite the JB3/JB5 primers being commonly used in molecular studies

621 of nematodes (Derycke et al. 2005, 2010, 2016, and Avó et al. 2017) few Enoploides sequences

622 were available on GenBank to produce a meaningful phylogenetic analysis. Instead, the pairwise

623 distance of all available Enoploides mtCOI sequences was calculated using K2P-substitution

624 model using MEGA 7.0. There was no genetic divergence between the new species, while in

625 comparison to other congeners, $19 \%$ to $24 \%$ divergence was seen (Table 4 ). This is well within

626 range to genetic divergence seen between congeners using mtCOI sequences (Derycke et al.

627 2010).

628

629

\section{8s rRNA}

630 We successfully amplified and sequenced DNA of four Enoploides koreanus sp. nov. and two

631 Epacanthion hirsutum. To test how our sequences group with existing sequences on GenBank, 632 we rebuilt 18S rRNA ML tree by Pereira et al. (2010) with most Enoploides 18S sequences 633 available on GenBank (listed in Table 5). The reason for selecting their tree was because their 634 study dealt with a number of free-living marine nematodes (especially Thoracostomopsidae) and 635 used the same primer sets utilized in the present study. The ML tree was more or less similar to 636 the one provided by Pereira et al. (2010), with Thoracostomopsidae forming monophyletic clade 637 with 100\% bootstrap. Enoploides koreanus and Epacanthion hirsutum sequences obtained from 638 this study both formed a clade with their respective congener species, with $83 \%$ and $78 \%$ 639 bootstraps respectively (Fig. 6). One 18S rRNA sequence of Epacanthion hirsutum (MG599065) 640 on GenBank was also retrieved to examine similarities. Although this sequence is considerably 641 longer than ours (1671 bp vs. 310-311 bp), for regions which do overlap, they showed no 642 differences at any of the sites. Sequences obtained in this study have been submitted to GenBank 643 and their accession numbers are MN514234-MN514242 (mtCOI) and MN512311-MN512318 644 (18S).

645

\section{Discussion}

647 One matter unresolved from this revision is the synonymy and confusion of species Enoploides 648 spiculohamatus, E. labiatus and E. longispiculosus. Both Wieser \& Hopper (1967) and Benwell 649 (1981) suggested abandoning the issue as it cannot be proven. The main problem is that the 650 original descriptions (Bresslau \& Stekhoven, 1940; Stekhoven, 1935) are poor and in the case of 651 Stekhoven (1935), it may not even be E. spiculohamatus according to Benwell (1981). As 652 nothing can be done about these species, they are left as valid species, but the fact that diagnostic 653 features of E. labiatus and E. longispiculosus are nearly identical to one another remains 654 problematic (Table 2).

655 The genus Enoploides currently consists of 27 valid species. The most recent review by

656 Smol et al. (2014) reported 28 valid species. It is unclear which exact species were listed as valid 657 during their report, as a full species list was not provided. Aside from a list of doubtful species 
658 provided by Wieser \& Hopper (1967), one more species was transferred to species inquirenda

659

660

661

662

663

664

665

666

667

668

669

670

671

672

673

674

675

676

677

678

679

680

681

682

683

684

685

686

687

688

689

690

691

692

693

694

695

696

697

through this revision. Enoploides filicaudatum is one of three species transferred from

Epacanthion by Greenslade \& Nicholas (1991). While mandibles may resemble those seen in the genus Enoploides, the fact that the original description was based on two juveniles is problematic. Mawson (1956) pointed out that the distinguishing characteristic of this species is the shape of its tail. Such an ambiguous characteristic should not be used as sole reason to discern species, and thus it is regarded as species inquirenda.

\section{Conclusion}

Our work reports Enoploides koreanus sp. nov., and Epacanthion hirsutum from Jeju Island, Korea. The new species belongs to a group with short spicules $(<150 \mu \mathrm{m})$ and is closely related to E. disparilis and E. cirrhatus based on simplicity and similarity of the spicules and gubernaculum. However, these two species lack the pre-anal supplementary organ present in the new species. Their body ratios also differ to certain degree. Amplification success with the 18S rRNA gene allowed us to visualize the phylogenetic position of our species, which formed clades with their respective congeners with acceptable bootstraps. From compiling and comparing valid species of the genus, we also agree with Wieser \& Hopper (1967), that basing descriptions on females and juveniles is ill-advised for this genus, as both lack the distinguishable morphological characteristics evident in males, such as pilosity of the head, morphology of the spicule and gubernaculum, and presence or absence of the pre/post-anal supplementary organ. A bibliographic review of the genus has updated the diagnosis and list of valid species to 27 , and a new key to the genus as well as tabular key comparing diagnostic characters of all valid species within the genus have been provided. Epacanthion hirsutum reported in Korea agrees with the original description provided by Shi \& Xu (2016). Its distinguishing character, a single row of densely arrange setae below the nerve ring, is easily discernible and there were no discrepancies with any of the measurements when compared with the original (Table 3).

\section{Acknowledgements}

We would like to thank Jaehyun Kim and Jisu Yeom for their insight on molecular analysis.

\section{References}

Allgén, C.A. (1929) Freilebende marine Nematoden aus der Umgebung der Staatlichen Zoologischen Station Kristineberg as der Westkuste Schwedens. Capita Zoologica, 2, 152.

Allgén, C.A. (1933) Freilebende Nematoden aus dem Trondhjemefjord. Capita Zoologica, 4 (2), $1-162$.

Allgén, C.A. (1940) Über einige norwegische marine Tiefen-Nematoden, Folia Zoologica et Hydrobiologica, 10, 258-281.

Allgén, C.A. (1946) Letzter Bericht über freilebende Nematoden aus dem Schalensand- und Kiesboden der Westküste Norwegens. Arkiv för Zoologi, 37A (15), 1-26. 
698

699

700

701

702

703

704

705

706

707

708

709

710

711

712

713

714

715

716

717

718

719

720

721

722

723

724

725

726

727

728

729

730

731

732

733

734

735

736

Allgén, C.A. (1953) Revision der freilebenden marinen Nematoden aus der Umgebung der Staatlichen Zoologischen Station Kristineberg an der Westküste Schwedens. Zoologische Jahrbücher (Systematik), 81, 548-603.

Altschul, S.F., Gish, W., Miller, W., Myers, E.W. \& Lipman, D.J. (1990) Basic local alignment search tool. Journal of Molecular Biology, 215, 403-410.

Avó, A.P., Daniell, T.J., Neilson, R., Oliveira, S., Branco, J. \& Adão, H. (2017) DNA Barcoding and Morphological Identification of Benthic Nematodes Assemblages of Estuarine Intertidal Sediments: Advances in Molecular Tools for Biodiversity Assessment. Frontiers in Marine Science, 4, 66. https://doi.org/10.3389/fmars.2017.00066

Benwell, M.P. (1981) A new species of Gonionchus (Nematoda, Xyalidae) from the Firth of Clyde, with a redescription of Enoploides spiculohamatus Schulz (Nematoda, Enoplidae). Cahiers de Biologie Marine, XXII: 177-184.

Bezerra, T.N., Decraemer, W., Eisendle-Flöckner, U., Hodda, M., Holovachov, O., Leduc, D., Miljutin, D., Mokievsky, V., Peña Santiago, R., Sharma, J., Smol, N., Tchesunov, A., Venekey, V., Zhao, Z. \& Vanreusel, A. (2019) Nemys: World Database of Nematodes. Accessed from: http://nemys.ugent.be (accessed 19 September 2019) https://doi.org/10.14284/366

Bhadury, P., Austen, M.C., Bilton, D.T., Lambshead, P.J.D., Rogers, A.D. \& Smerdon, G.R. (2006) Development and evaluation of a DNA-barcoding approach for the rapid identification of nematodes. Marine Ecology Progress Series, 320, 1-9.

Bik, H.M., Lambshead, P.J.D., Thomas, W.K. \& Lunt, D.H. (2010) Moving towards a complete molecular framework of the Nematoda: a focus on the Enoplida and early branching clades. BMC Evolutionary Biology, 10 (1), 353. https:// doi:10.1186/1471-2148-10-353

Boucher, G. (1977) Nématodes des sables fins infralittoraux de la Pierre Noue (Manche occidentale). IV. Enoplida. Bulletin du Muséum National d'histoire naturelle, Zoologie, $325,733-752$.

Bouwman, L.A. (1981) Systematics, ecology and feeding biology of estuarine nematodes. PhD thesis, Wageningen, $173 \mathrm{pp}$.

Bresslau, E. \& Schuurmans Stekhoven, J.H. (1940) Marine freilebende Nematoda aus der Nordsee. Musée royal d'Histoire naturelle de Belgique, Bruxelles, 74 pp.

Brunetti, B. (1949) Contributo alla conoscenza dei Nematodi del M. Tirreno. II. Alcune specie appartenenti alle famiglie: Enoplidae, Cyatholaimidae, Chromadoridae, Axonolaimidae. Monitore Zoologico Italiano, 57, 41-59.

Burgess, R. (2001) An improved protocol for separating meiofauna from sediments using colloidal silica sols. Marine Ecology Progress Series, 214, 161-165. https://doi.org/10.3354/meps 214161

Bussau, C. (1993) Taxonomische und ökologische Untersuchungen an Nematoden des PeruBeckens. Dissertation zur Erlangung des Doktorgrades der MathematischNaturwissenschaftlichen, Fakultät der Christian-Albrechts-Universität zu Kiel, 1-625.

Peer) reviewing PDF | (2019:10:41933:3:0:NEW 23 Mar 2020) 
737

738

739

740

741

742

743

744

745

746

747

748

749

750

751

752

753

754

755

756

757

758

759

760

761

762

763

764

765

766

767

768

769

770

771

772

773

774

775

776

Bütschli, O. (1874) Zur Kenntnis der freilebenden Nematoden, insbesondere der des Kieler Hafens. Abhandlungen der Senckenbergischen Naturforschenden Gesellschaft, IX. Bd, 1-56.

Coles, J.W. (1977) Freeliving marine nematodes from Southern Africa. Bulletin of the British Museum (Natural History), 31 (1), 3-49.

De Coninck, L.A. (1965) Classe des Nématodes-Systématique des Nématodes et sous-classe des Adenophorea. In: Grassé, P. (Ed.) Traité de Zoologie. Masson, Paris, 4, 586-681.

De Coninck, L.A. \& Schuurmans Stekhoven, J.H. (1933) The freeliving marine nemas of the Belgian Coast. II With general remarks on the structure and the system of nemas. Mémoires du Musée royal d'histoire naturelle de Belgique, 58, 3-163.

de Man, J.G. (1893). Cinquième Note sur les Nématodes libres de la mer du Nord et de la Manche. Mémoires de la Société zoologique de France, 6, 81-125.

Derycke, S., Remerie, T., Vierstraete, A., Backeljau, T., Vanileteren, J., Vincx, M. \& Moens, T. (2005) Mitochondrial DNA variation and cryptic speciation within the free-living marine nematode Pellioditis marina, Marine Ecology Progress Series, 300, 91-103.

Derycke, S., Vanaverbeke, J., Rigaux, A., Backeljau, T. \& Moens, T. (2010) Exploring the use of cytochrome oxidase c subunit 1 (COI) for DNA barcoding of free-living marine nematodes. PLoS ONE, 5 (10), e13716. doi:10.1371/journal.pone.0013716

Derycke, S., De Meester, N., Rigaux, A., Creer, S., Bik, H., Thomas, W.K. \& Moens, T. (2016) Coexisting cryptic species of the Litoditis marina complex (Nematoda) show differential resource use and have distinct microbiomes with high intraspecific variability. Molecular Ecology, 25, 2093-2110. doi:10.1111/mec.13597

Ditlevsen, H. (1918) Marine freeliving nematodes from Danish waters. Videnskabelige Meddelelser fra Dansk Naturhistorisk Forening i Kjøbenhavn, 70, 147-214.Ditlevsen, H. (1926) Free-living nematodes. The Danish Ingolf Expedition Volume IV, 6, 1-42.

Dujardin, F. (1845). Histoire naturelle des helminthes ou vers Intestinaux. Librairie encyclopédique de Roret, Paris, 654 pp.

Filipjev, I.N. (1918) Free-Living Marine Nematodes of the Sevastopol Area. Transactions of the Zoological Laboratory and the Sevastopol Biological Station of the Russian Academy of Sciences. Series II, N4, (Issue I). (Translated from Russian).

Filipjev, I.N. (1921) Free-Living Marine Nematodes of the Sevastopol Area. Transactions of the Zoological Laboratory and the Sevastopol Biological Station of the Russian Academy of Sciences. Series II, N4, (Issue II). (Translated from Russian).

Filipjev, I.N. (1927) Les Nematodes libres des mers septentrionales appurtenant a la famille des Enoplidae. Archiv für Naturgeschichte, 91A (6), 1-216.

Filipjev, I.N. (1929) Classification of freeliving Nematoda and relations to parasitic forms. Journal of Parasitology, 15, 281-282.

Gerlach, S.A. (1953) Die Nematodenbesiedlung des Sandstrandes und des Küstengrundwassers an der italienischen Küste I. Systematischer Teil. Archivio Zoologico Italiano, 37, 517640 .

Peer) reviewing PDF | (2019:10:41933:3:0:NEW 23 Mar 2020) 
777 Gerlach, S.A. (1957) Die Nematodenfauna des Sandstrandes an der Küste von Mittelbrasilien

778

779

780

781

782

783

784

785

786

787

788

789

790

791

792

793

794

795

796

797

798

799

800

801

802

803

804

805

806

807

808

809

810

811

812

813

814 (Brasilianische Meerse-Nematoden IV). Mitteilungen aus dem Zoologischen Museum in Berlin, 33 (2), 411-459.

Gerlach, S.A. \& Riemann, F. (1974) The Bremerhaven checklist of aquatic nematodes. A catalogue of Nematoda Adenophorea excluding the Dorylaimida. Part

2. Veröffentlichungen des Instituts für Meeresforschung in Bremerhaven, Supplement 4, 405-736.

Greenslade, P. \& Nicholas, W. (1991) Some Thoracostomopsidae (Nematoda: Enoplida) from Australia, including descriptions of two new genera and diagnostic keys. Invertebrate Systematics, 4, 1031-1052.

Hooper, D. (1986) Drawing and measuring nematodes. In: Laboratory Methods for Work with Plant and Soil Nematodes. Ministry of Agriculture, Fisheries and Food, Her Majesty's Stationery Office, London, 87-94.

ICZN (1999) International Code of Zoological Nomenclature, 4th Edition. The Natural Museum, London, $306 \mathrm{pp}$.

Jensen, P. (1986) The nematode fauna in the sulphide-rich brine seep and adjacent bottoms of the East Flower Garden, NW Gulf of Mexico. III. Enoplida. Zoologica Scripta, 15 (2), $93-$ 99.

Kimura, M. (1980) A simple method for estimating evolutionary rates of base substitutions through comparative studies of nucleotide sequences. Journal of Molecular Evolution, 16 (2), 111-120. doi:10.1007/BF01731581

Kumar, S., Stecher, G. \& Tamura, K. (2016) MEGA ver. 7.0.26: molecular evolutionary genetics analysis version 7.0 for bigger datasets. Marine Biology and Evolution, 33, 1870-1874.

Mawson, P.M. (1956) Free-living nematodes. Section 1: Enoploidea from Antarctic stations. B.A.N.Z. Antarctic Research Expedition Reports, Series B, 6 (3), 37-74.

Mawson, P.M. (1958) Free-living nematodes. Section 3: Enoploidea from Subantarctic stations. B.A.N.Z. Antarctic Research Expedition Reports, Series B, 6 (14), 307-358.

Meldal, B.H.M. (2004) Phylogenetic systematics of the phylum Nematoda - evidence from molecules and morphology. PhD Thesis, University of Southampton.

Mikoletzky, H. (1923) Freilebende Nematoden der Wolga mit bersonderer Berücksichtigung der Umgebung von Saratow. Arbeiten der Biologischen Wolga-Station, 7 (1-2), 3-29.

Nicholas, W.L. (1993) Two new species of nematode (Nematoda: Enoplida: Thoracostomopsidae) from Lake Alexandrina, South Australia. Transactions of the Royal Society of South Australia, 117 (4), 163-170.

Pavljuk, O.N. (1984) New Species of Marine Free-Living Nematodes in the Sea of Japan and Comments to the Genus Halanonchus (Novye Vidy Morskikh Svobodnozhivushchikh Nematod Iaponskogo Moria i Zamechaniia o Rode Halanonchus). Zoologicheskii Zhurnal, 63 (8), 1144-1149. 
815 Pereira, T.J., Fonseca, G., Mundo-Ocampo, M., Guilherme, B.C. \& Rocha-Olivares, A. (2010) 816 Diversity of free-living marine nematodes (Enoplida) from Baja California assessed by 817 integrative taxonomy. Marine Biology, 157, 1665-1678.

818 Phillips, G., Bernard, E.C., Pivar, R.J., Moulton, J.K. \& Shelley, R.M. (2016) Coronostoma 819 claireae n. sp. (Nematoda: Rhabditida: Oxyuridomorpha: Coronostomatidae) from the

820

821

822

823

824

825

826

827

828

829

830

831

832

833

834

835

836

837

838

839

840

841

842

843

844

845

846

847

848

849

850

851

852

853

Indigenous Milliped Narceus gordanus (Chamberlain, 1943) (Diplopoda: Spirobolida) in Ocala National Forest, Florida. Journal of Nematology, 48 (3), 159-169. doi: 10.21307/jofnem-2017-023

Platt, H. \& Warwick, R.M. (1983) Free-living Marine Nematodes. Part I. British Enoplids. In: Kermack, D.M. \& Barnes, R.S.K. (Eds.), Synopses of British Fauna (New Series) n. 28, Cambridge University Press, Cambridge, pp. 307.

Rambaut, A. (2009) FigTree version 1.4.4. Available from http://tree.bio.ed.ac.uk/software/figtree/ (accessed September 1 2019)

Riemann, F. (1966) Die interstitielle Fauna im Elbe-Aestuar. Verbreitung und Systematik. Archiv für Hydrobiologie Supplementband, 31, pp. 279.

Schulz, E. (1932) Beiträge zur Kenntnis mariner Nematoden aus der Kieler Bucht. Zoologische Jahrbücher Jena (Systematik), 62, 331-430.

Schuurmans Stekhoven, J.H. Jr. (1935) Nematoda: Systematischer Teil, Nematoda errantia. In: Grimpe, G. \& Wagler, E. (Eds) Die Tierwelt der Nord- und Ostsee, Anon., Leipzig, 5, 1173.

Schuurmans Stekhoven, J.H. Jr. (1943) Freilebende marine Nematoden des Mittelmeeres. IV. Freilebende marine Nematoden der Fischereigründe bei Alexandrien. Zool. Jb. (Syst.), 76 (4), 323-378.

Schuurmans Stekhoven, J.H. Jr. (1946) Freilebende marine Nematoden des Skagerraks und der Umgebung von Stocklholm. Arkiv för Zoologi, Band 37 A, No 16, 1-91.

Schuurmans Stekhoven, J.H. Jr. (1950) The freeliving marine nemas of the Meditteranean I. The Bay of Villefranche. Mémoires de l'institut royal des sciences naturelles de Belgique, 37 (2), 1-220.

Seinhorst, J. (1959) A rapid method for the transfer of nematodes from fixative to anhydrous glycerin. Nematologica, 4, 67-69. https://doi.org/10.1163/187529259X00381

Sergeeva, N.G. (1974) New Free-living Nematodes (Enoplida) from the Black Sea, Report 2 (Novye Vidy Svobodnozhivushchikh Nematod Otriada (Enoplida) iz Chernogo Moria, Soobshchenie 2). Zoologicheskii Zhurnal, 53 (1), 120-125.

Shi, B. \& Xu, K. (2016) Four new species of Epacanthion Wieser, 1953 (Nematoda: Thoracostomopsidae) in intertidal sediments of the Nanji Islands from the East China Sea. Zootaxa, 4085 (4), 557-574.

Smol, N., Muthumbi, A. \& Sharma, J. (2014) 7.3 Order Enoplida. In: Schmidt-Rhaesa, A. (Ed.), Handbook of zoology. Gastrotricha, Cycloneuralia, Gnathifera. Vol. 2. Nematoda. De Gruyter, Berlin, pp. 193-249.

Peer) reviewing PDF | (2019:10:41933:3:0:NEW 23 Mar 2020) 
854 Southern, R. (1914) Nemathelmia, Kinorhyncha and Cheatognatha (Clare Island survey, part 54).

855

856

857

858

859

860

861

862

863

864

865

866

867

868

869

870

871

872

873

874

875

876

877

878

879

880

881

882

883

884 Proceedings of the Royal Irish Academy, 31, 1-80.

Ssaweljev, S. (1912) Zur Kenntnis der freilebenden Nematoden des Kolafjords und des Relictensee Mogilnoje. Travaux de la Société (Impériales) des Naturalistes de SaintPetersbourg, 43, 108-126.

Steiner, G. (1921) Untersuchungen über den allgemeinen Bauplan des Nematodenkörpers. Ein Beitrag zur Aufhellung der Stammesgeschichte und der Verwandtschaftsverhältnisse der Nematoden, Zoologische Jahrbücher Abteilung für Anatomie, 43, 1-96.

Tamura, K. (1992) Estimation of the number of nucleotide substitutions when there are strong transition-transversion and G $+\mathrm{C}$-content biases. Molecular Biology and Evolution, 9 , 678-687.

Thompson, J.D., Higgins, D.G. \& Gibson, T.J. (1994) CLUSTAL W: improving the sensitivity of progressive multiple sequence alignment through sequence weighting, position specific gap penalties and weight matrix choice. Nucleic Acids Research, 22, 4673-4680.

Vitiello, P. (1967) Nématodes libres marins de Roscoff. I. Description de cinq espèces nouvelles. Cahiers de Biologie Marine, 8, 403-416.

Warwick, R.M. (1971) Nematode associations in the Exe Estuary. Journal of the Marine Biological Association of the United Kingdom, 51, 439-454.

Wieser, W. (1953) Reports of the Lund University Chile expedition 1948-49: 10. Free-living marine nematodes I. Enoploidea. Lunds Universitets Arsskrift 49 (6), 155 pp.

Wieser, W. (1959) Free-living nematodes and other small invertebrates of Puget Sound beaches. In: University of Washington Publications in Biology. Vol. 19. University of Washington Press, Seattle, pp. 1-179.

Wieser, W. \& Hopper, B. (1967) Marine nematodes of the east coast of North America. I. Florida. Bulletin of the Museum of Comparative Zoology at Harvard College, 135 (5), 239-344.

Williams, B.D., Schrank, B., Huynh, C., Shownkeen, R. \&Waterston, R.H. (1992) A genetic mapping system in Caenorhabditis elegans based on polymorphic sequence-tagged sites. Genetics, 131, 609-624. 
885 Tables

886

887

Table 1. Measurement of major morphological characters of Enoploides koreanus sp. nov.

888 Measurements are in $\mu \mathrm{m}$ where applicable, and morphometric values are rounded.

889 Table 2. Comparison of diagnostic morphological characters of all Enoploides species. Males 890 only, morphometric values are rounded. Species with spicules shorter than $150 \mu \mathrm{m}$ are

891

892

893

894

895

896

897

898

899

900

901

902

903

904

905

906

907

908

909

910

911

912

913

914

915

916

917

918

919

920

921

922 marked with asterisk.

Table 3. Comparison of diagnostic morphological characters between Epacanthion hirsutum found from Korea and from original description. Males only, morphometric values are rounded.

Table 4. Kimura 2-parameter distance between all available sequences of Enoploides species based on mtCOI alignment.

Table 5. Sequences retrieved from GenBank for phylogenetic analysis of this study.

\section{Figures}

Figure 1. Head region, showing different type of mandibles. (A) Enoploides koreanus sp. nov., male. (B) Epacanthion hirsutum Shi \& Xu, 2016., male. Scale bars: $20 \mu \mathrm{m}$ (A and B).

Figure 2. Enoploides koreanus sp. nov. male. (A) head, lateral view. (B) total view. (C) tail, with spicules, gubernaculum and preanal supplementary organ. Scale bars: $30 \mu \mathrm{m}$ (A and C) and $100 \mu \mathrm{m}(\mathrm{B})$. Figure credit: Raehyuk Jeong.

Figure 3. Enoploides koreanus sp. nov. female. (A) head, lateral view. (B) tail region with caudal glands. (C) reproductive system with vulva. (D) total view. Scale bars: $20 \mu \mathrm{m}$ (A and B), $40 \mu \mathrm{m}(\mathrm{C})$ and $100 \mu \mathrm{m}$ (D). Figure credit: Raehyuk Jeong.

Figure 4. Scanning electron micrograph of Enoploides koreanus sp. nov. (A) male, head region, lateral view, arrow showing seemingly three setae (presumed to be ols, cs, and scs) tangled to one another. (B) male, tail region, arrows showing several caudal setae. (C) male, cloacal opening with arrow showing round head of gubernaculum peeking out, behind it two spicules extending outwards. (D) female, head region, lateral view, with arrows showing short subcephalic setae below outer labial and cephalic setae. (E) female, mouth region, subapical view, showing lip configuration. (F) female, cloacal region, ventral view. Scale bars: $10 \mu \mathrm{m}$.

Figure 5. Epacanthion hirsutum Shi \& Xu, 2016. male. (A) head, lateral view. (B) tail region with spicules and gubernaculum. Scale bars: $30 \mu \mathrm{m}$ (A and B). Figure credit: Raehyuk Jeong.

Figure 6. Maximum likelihood tree of $18 \mathrm{~S}$ rRNA gene based on TPM3+G (with bootstrap values shown at each nodes; 1000 replicates). 
Figure 1

Head region, showing different type of mandibles.

(A) Enoploides koreanus sp. nov., male. (B) Epacanthion hirsutum Shi \& Xu, 2016., male.

Scale bars: $20 \mu \mathrm{m}$ (A and B).

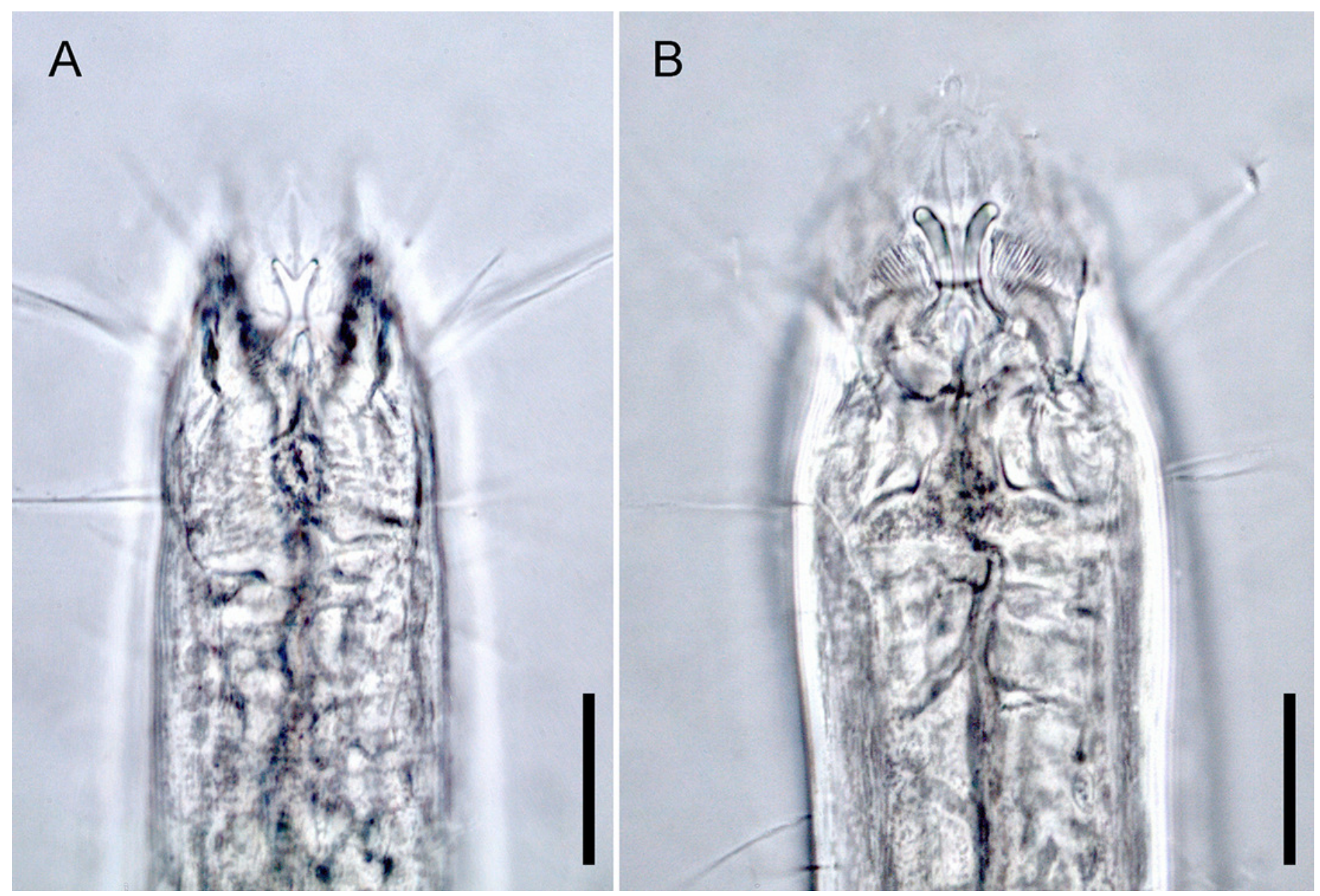


Figure 2

Enoploides koreanus sp. nov. male.

(A) head, lateral view. (B) total view. (C) tail, with spicules, gubernaculum and preanal supplementary organ. Scale bars: $30 \mu \mathrm{m}$ ( $\mathrm{A}$ and C) and $100 \mu \mathrm{m}$ (B). Figure credit: Raehyuk Jeong. 


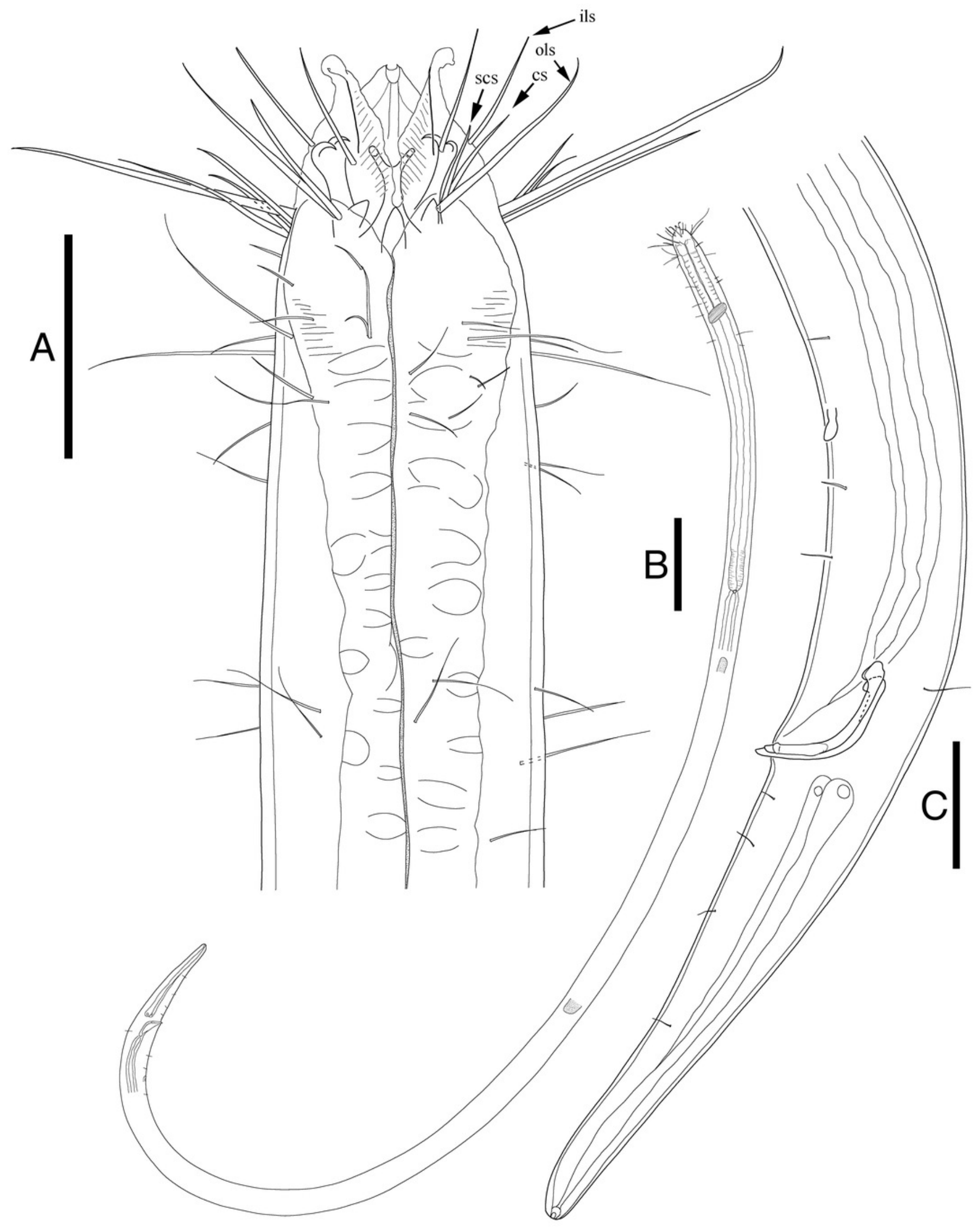


Figure 3

Enoploides koreanus sp. nov. female.

(A) head, lateral view. (B) tail region with caudal glands. (C) reproductive system with vulva.

(D) total view. Scale bars: $20 \mu \mathrm{m}$ (A and B), $40 \mu \mathrm{m}$ (C) and $100 \mu \mathrm{m}$ (D). Figure credit:

Raehyuk Jeong. 


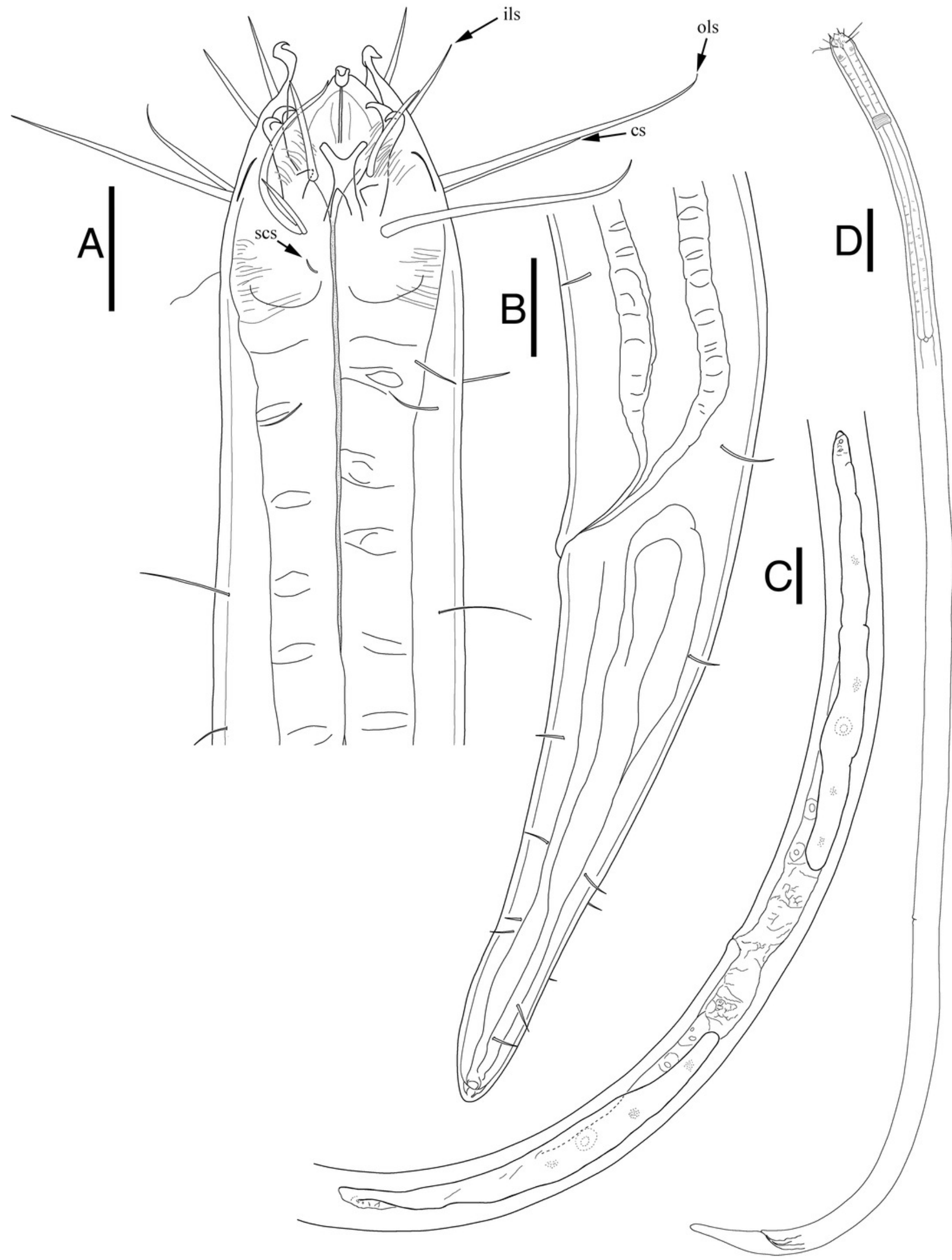




\section{Figure 4}

Scanning electron micrograph of Enoploides koreanus sp. nov.

(A) male, head region, lateral view, many subcephalic setae on head region tangled to one another. (B) male, tail region, arrows showing several caudal setae. (C) male, cloacal opening with arrow showing round head of gubernaculum peeking out, behind it two spicules extending outwards. (D) female, head region, lateral view, with arrows showing short subcephalic setae below outer labial and cephalic setae. (E) female, mouth region, subapical view, showing lip configuration. (F) female, cloacal region, ventral view. Scale bars: $10 \mu \mathrm{m}$. 


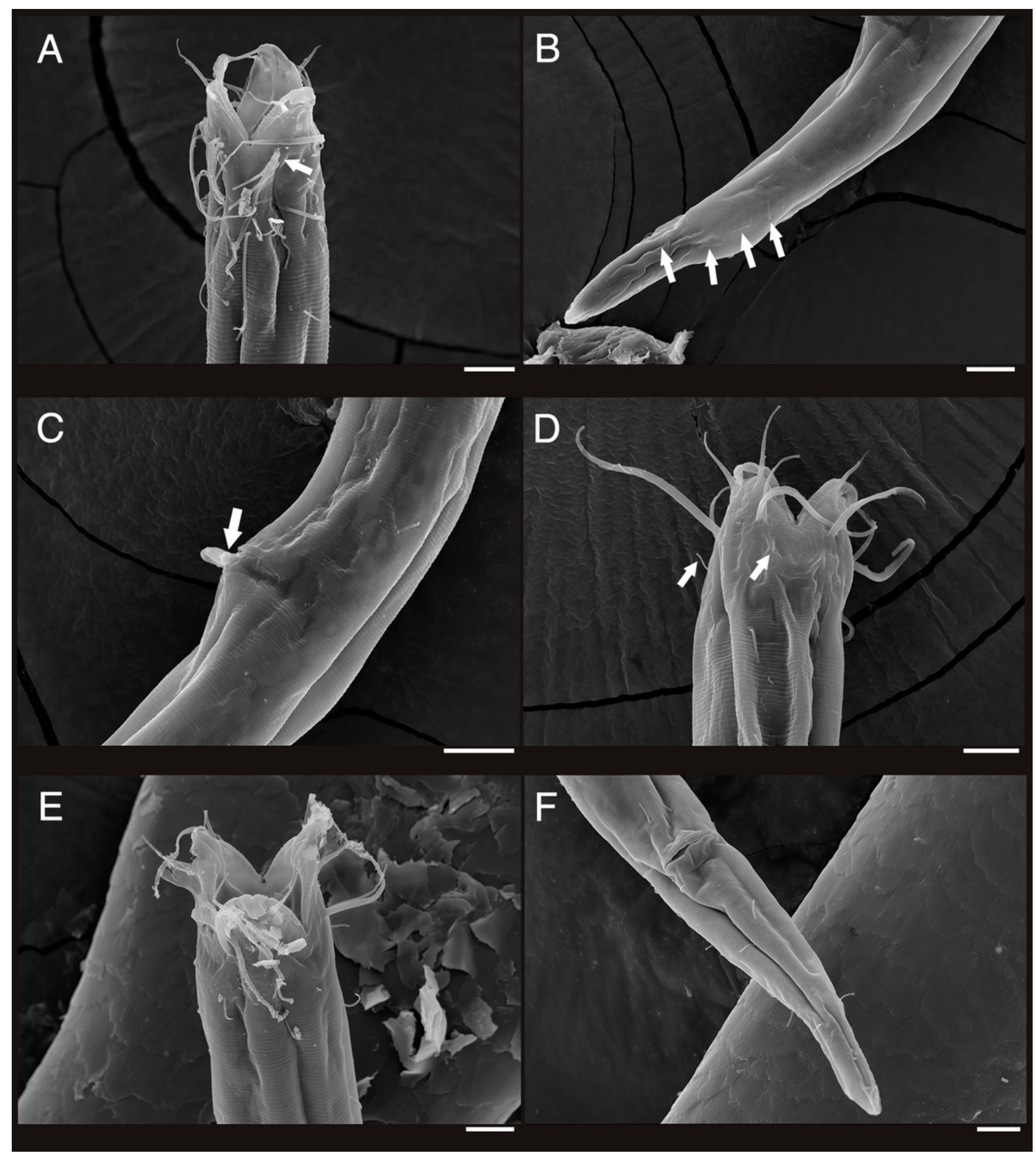


Figure 5

Epacanthion hirsutum Shi \& Xu, 2016. male.

(A) head, lateral view. (B) tail region with spicules and gubernaculum. Scale bars: $30 \mu \mathrm{m}$ (A and B). Figure credit: Raehyuk Jeong. 


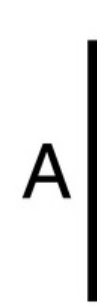

A

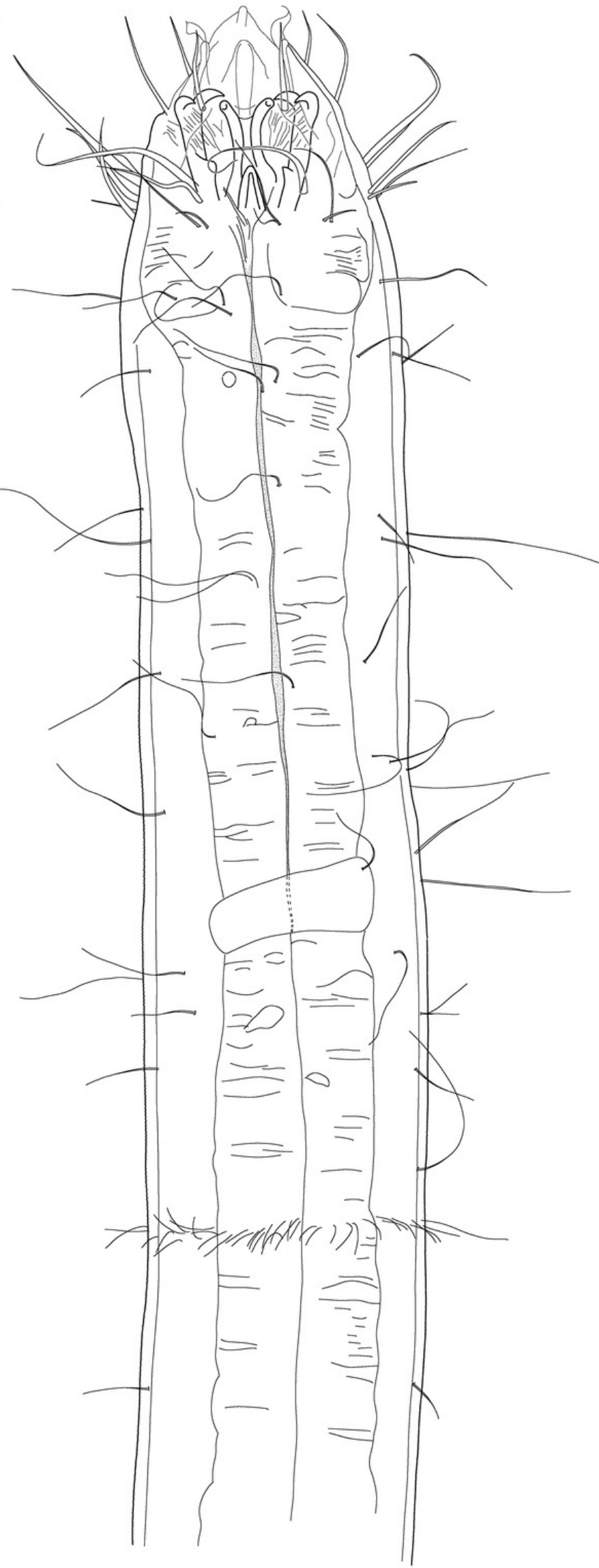

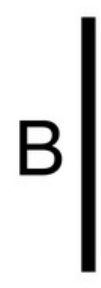

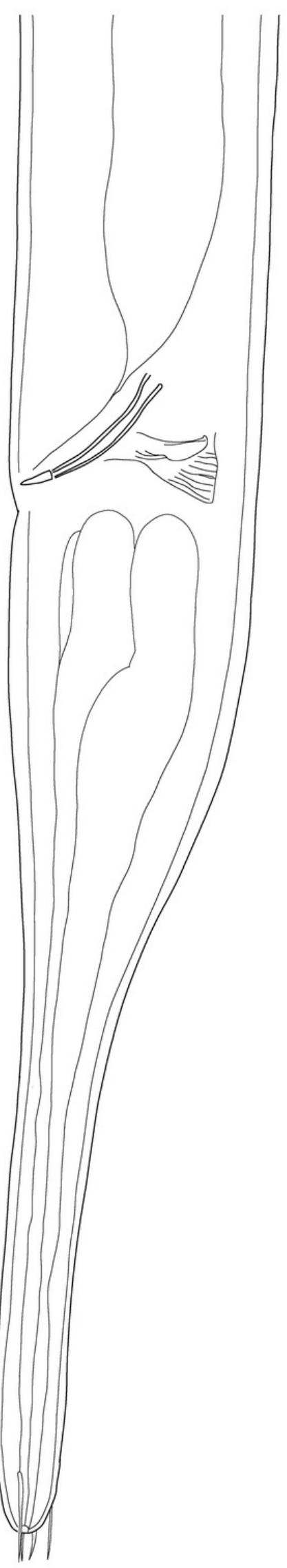




\section{Figure 6}

\section{Maximum likelihood tree of 18S rRNA gene based on TPM3+G.}

(with bootstrap values shown at each nodes; 1000 replicates).

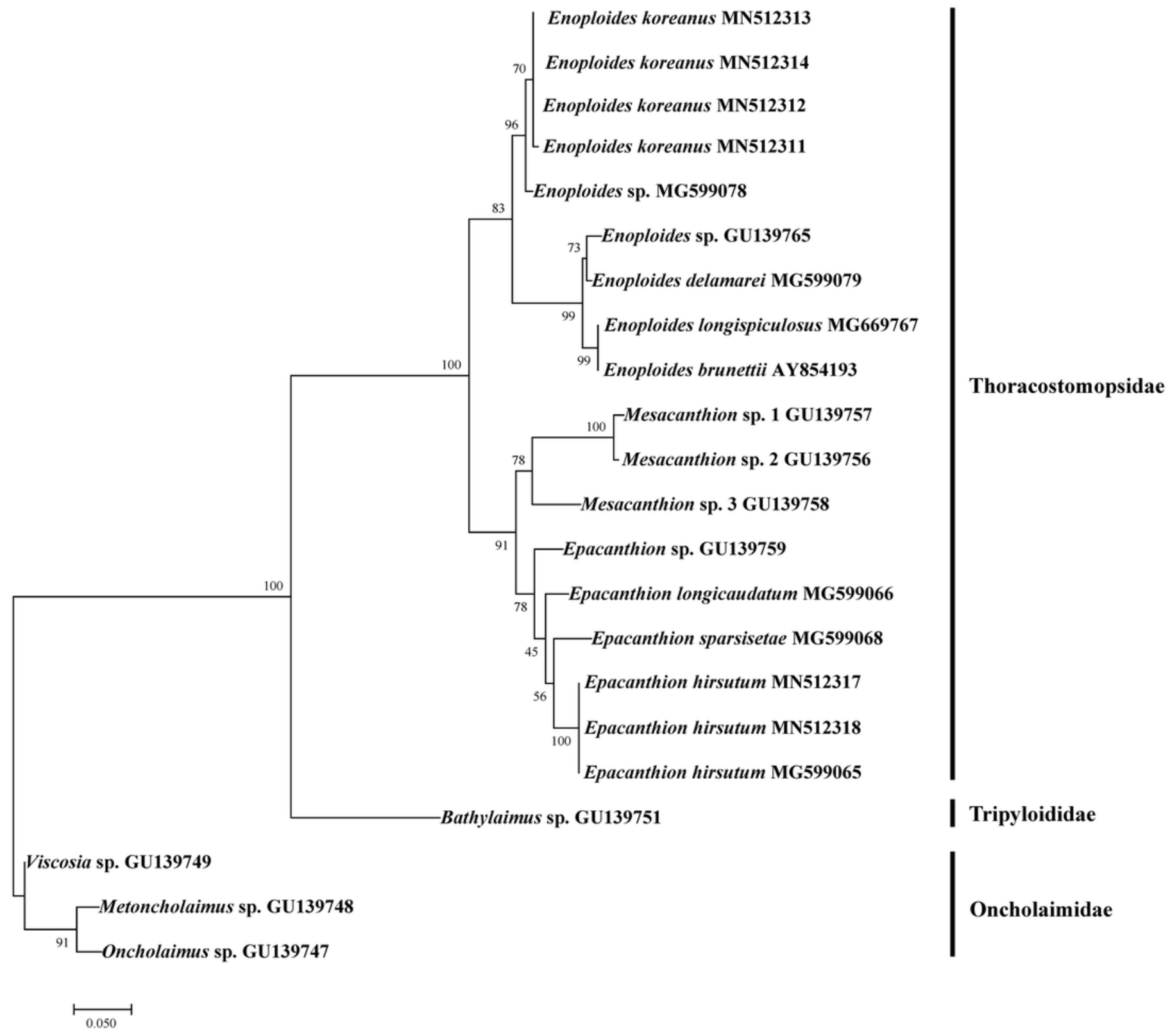




\section{Table $\mathbf{1}$ (on next page)}

Measurement of major morphological characters of Enoploides koreanus sp. nov.

Measurements are in $\mu \mathrm{m}$ where applicable, and morphometric values rounded. 


\begin{tabular}{|c|c|c|c|}
\hline Characters & $\begin{array}{c}ð \\
\text { holotype }\end{array}$ & $\begin{array}{c}\delta(n=3) \\
\text { mean } \pm \text { sd (range) }\end{array}$ & $\begin{array}{c}\uparrow(\mathbf{n}=6) \\
\text { mean } \pm \text { sd (range) }\end{array}$ \\
\hline body length & 2107 & $2209 \pm 100(2107-2307)$ & $2136 \pm 159(1851-2292)$ \\
\hline maximum body diameter & 36 & $35 \pm 2(33-36)$ & $42 \pm 3(39-47)$ \\
\hline diameter at the level of cephalic setae & 29 & $29 \pm 1(29-30)$ & $29 \pm 6(18-34)$ \\
\hline length of inner labial setae & 11 & $14 \pm 4(11-18)$ & $17 \pm 1(16-19)$ \\
\hline length of outer labial setae & 43 & $37 \pm 7(30-43)$ & $42 \pm 4(39-48)$ \\
\hline length of cephalic setae & 15 & $15 \pm 4(11-18)$ & $17 \pm 3(13-20)$ \\
\hline distance from anterior to cephalic setae & 13 & $18 \pm 5(13-23)$ & $23 \pm 3(19-27)$ \\
\hline width at cephalic capsule end & 34 & $34 \pm 0(34-34)$ & $37 \pm 2(32-38)$ \\
\hline mandible length & 12 & $11 \pm 1(10-12)$ & $12 \pm 1(10-13)$ \\
\hline tooth length & 5 & $5 \pm 0(5-5)$ & $6 \pm 1(5-6)$ \\
\hline buccal cavity length & 18 & $24 \pm 6(18-29)$ & $29 \pm 2(26-30)$ \\
\hline distance from nerve ring from anterior end & 127 & $127 \pm 10(117-137)$ & $133 \pm 9(119-143)$ \\
\hline pharynx (oesophagus) length & 510 & $527 \pm 17(510-543)$ & $524 \pm 30(488-558)$ \\
\hline corresponding body diameter at pharynx & 36 & $35 \pm 2(33-36)$ & $40 \pm 2(36-42)$ \\
\hline cardia length & 13 & $10 \pm 3(8-13)$ & $9 \pm 2(7-12)$ \\
\hline tail length & 130 & $125 \pm 5(121-130)$ & $114 \pm 8(100-122)$ \\
\hline anal body diameter & 31.0 & $31 \pm 2(29-33)$ & $33 \pm 3(29-36)$ \\
\hline$c^{\prime}$ & 4 & $4 \pm 0(3.7-4.2)$ & $3.5 \pm 0(3.3-3.8)$ \\
\hline spicule length as arc & 39.0 & $36 \pm 3(34-39)$ & $\mathrm{n} / \mathrm{a}$ \\
\hline spicule length as arc / anal body diameter & 1 & $1.2 \pm 0(1.1-1.3)$ & $\mathrm{n} / \mathrm{a}$ \\
\hline length of gubernaculum & 12 & $12 \pm 1(11-12)$ & $\mathrm{n} / \mathrm{a}$ \\
\hline supplementary organ length & 8 & $9 \pm 1(8-9)$ & $\mathrm{n} / \mathrm{a}$ \\
\hline $\begin{array}{l}\text { distance from cloacal opening to supplementary } \\
\text { organ }\end{array}$ & 82.0 & $85 \pm 3(82-87)$ & $\mathrm{n} / \mathrm{a}$ \\
\hline distance from anterior end to vulva & $\mathrm{n} / \mathrm{a}$ & $\mathrm{n} / \mathrm{a}$ & $1355 \pm 111(1170-1456)$ \\
\hline corresponding body diameter at vulva & $\mathrm{n} / \mathrm{a}$ & $\mathrm{n} / \mathrm{a}$ & $42 \pm 3(39-47)$ \\
\hline $\begin{array}{l}\text { distance from anterior end to vulva as percentage of } \\
\text { total body length }\end{array}$ & $\mathrm{n} / \mathrm{a}$ & $\mathrm{n} / \mathrm{a}$ & $63 \pm 2(60-64)$ \\
\hline $\mathrm{a}$ & 58.5 & $63.8 \pm 4.6(58.5-67.1)$ & $50.6 \pm 5(47.5-58.8)$ \\
\hline $\mathrm{b}$ & 4.1 & $4.2 \pm 0.2(4.1-4.4)$ & $4.1 \pm 0(3.8-4.3)$ \\
\hline $\mathrm{c}$ & 16.2 & $17.8 \pm 1.4(16.2-18.8)$ & $18.7 \pm 1(17.5-20.4)$ \\
\hline
\end{tabular}

1

2 Table 1. Measurement of major morphological characters of Enoploides koreanus sp. nov.

3 Measurements are in $\mu \mathrm{m}$ where applicable, and morphometric values are rounded. 


\section{Table 2 (on next page)}

Comparison of diagnostic morphological characters of all Enoploides species.

Males only, morphometric values rounded. Species with spicules shorter than $150 \mu \mathrm{m}$ marked with asterisk. 


\begin{tabular}{|c|c|c|c|c|c|c|c|c|c|c|c|}
\hline \multirow[b]{2}{*}{ Species } & \multirow{2}{*}{$\begin{array}{c}\text { Body } \\
\text { length } \\
{[\mu \mathrm{m}]}\end{array}$} & \multirow[b]{2}{*}{ a } & \multirow[b]{2}{*}{ b } & \multirow[b]{2}{*}{ c } & \multirow[b]{2}{*}{$\mathbf{c}^{\prime}$} & \multicolumn{2}{|c|}{ Length of Setae } & \multirow{2}{*}{$\begin{array}{c}\text { Spicule } \\
\text { length }[\mu \mathrm{m}] \\
\text { (spicule } \\
\text { length as } \\
\text { arc/abd) } \\
\text { left/right if } \\
\text { applicable } \\
\end{array}$} & \multirow{2}{*}{$\begin{array}{l}\text { Gubernaculum } \\
\text { (length }[\mu \mathrm{m}])\end{array}$} & \multirow{2}{*}{$\begin{array}{c}\text { Gubernaculum } \\
\text { type }\end{array}$} & \multirow{2}{*}{$\begin{array}{c}\text { Supplementary } \\
\text { organ/papilla } \\
\text { distance from cloacal } \\
\text { opening [ } \mu \mathrm{m}] \\
\text { (supplementary } \\
\text { organ distance from } \\
\text { cloacal opening/abd) }\end{array}$} \\
\hline & & & & & & $\begin{array}{l}\text { Inner } \\
\text { labial } \\
\text { Setae }\end{array}$ & $\begin{array}{l}\text { Outer labial } \\
\text { setae/cephali } \\
\text { c setae }\end{array}$ & & & & \\
\hline $\begin{array}{l}\text { Enoploides amphioxi } \\
\text { Filipjev, } 1918\end{array}$ & 5400 & 51 & 5.5 & 26 & 4.2 & 24 & $50 / 24$ & $500(12.5)$ & present (65) & S-shaped & present (3.5) \\
\hline $\begin{array}{l}\text { Enoploides bisulcus } \\
\text { Wieser \& Hopper, } 1967\end{array}$ & $\begin{array}{l}3500- \\
4200\end{array}$ & $\begin{array}{l}\text { Not } \\
\text { measur } \\
\text { ed }\end{array}$ & $\begin{array}{l}\text { Not } \\
\text { meas } \\
\text { ured }\end{array}$ & $\begin{array}{l}20- \\
21 \\
\text { calc }\end{array}$ & 4 & 25 & $45-50 / 25-28$ & $420-475$ & $\begin{array}{l}\text { present (not } \\
\text { measured) }\end{array}$ & S-shaped & present $120-150$ \\
\hline $\begin{array}{l}\text { Enoploides brunettii } \\
\text { Gerlach, } 1953\end{array}$ & $\begin{array}{l}2060- \\
2045\end{array}$ & $29-36$ & $\begin{array}{l}4.5- \\
4.6\end{array}$ & $\begin{array}{l}14.7 \\
-16\end{array}$ & $3-3.5$ & $18-24$ & $45-53$ & $190(3-3.5)$ & present (36-39) & $\begin{array}{l}\text { Complex with } \\
\text { multiple parts }\end{array}$ & present (1.5-2) \\
\hline $\begin{array}{l}\text { Enoploides caspersi } \\
\text { Riemann, } 1966^{*}\end{array}$ & $\begin{array}{l}3900- \\
5150\end{array}$ & $54-60$ & 5.4 & 21.4 & $\begin{array}{l}\text { not } \\
\text { measur } \\
\text { ed }\end{array}$ & $27-31.5$ & $90 / 38$ & $\begin{array}{l}42.5-48(0.7 \\
\text { calc })\end{array}$ & present (62-72) & S-shaped & $\begin{array}{l}\text { present } 142-148 \text {, post- } \\
\text { anal supplementary } \\
\text { organ also present }\end{array}$ \\
\hline $\begin{array}{l}\text { Enoploides cephalophorus } \\
\text { (Ditlevsen, 1918) Filipjev, } \\
1927\end{array}$ & 3100 & 39 & 4.8 & 17.9 & $\begin{array}{l}\text { not } \\
\text { measur } \\
\text { ed }\end{array}$ & $\begin{array}{l}\text { not } \\
\text { measured }\end{array}$ & not measured & 264 & present & S-shaped & present 128 \\
\hline $\begin{array}{l}\text { Enoploides cirrhatus } \\
\text { Filipjev, 1918* }\end{array}$ & 4350 & 26 & 5.25 & 16 & 4.5 & 13 & 40 & $60(1)$ & present (15) & $\begin{array}{l}\text { Small, adjacent to } \\
\text { spicule on dorsal } \\
\text { side, upper edge } \\
\text { curved }\end{array}$ & $\begin{array}{l}\text { not mentioned, } 7-8 \\
\text { pre-anal papillae } \\
\text { present }\end{array}$ \\
\hline $\begin{array}{l}\text { Enoploides crassum } \\
\text { (Ditlevsen, 1926) } \\
\text { Greenslade \& Nicholas, } \\
1991\end{array}$ & 3000 & 21 & 3.9 & 17 & $\begin{array}{l}\text { not } \\
\text { measur } \\
\text { ed }\end{array}$ & $\begin{array}{l}\text { not } \\
\text { measured }\end{array}$ & not measured & "very long" & present & $\begin{array}{l}\text { Short plates on } \\
\text { distal end of spicule }\end{array}$ & $\begin{array}{l}\text { present (at level of } \\
\text { middle of spicule) }\end{array}$ \\
\hline $\begin{array}{l}\text { Enoploides delamarei } \\
\text { Boucher, } 1977\end{array}$ & $\begin{array}{l}2090- \\
2693\end{array}$ & $\begin{array}{l}37.3- \\
43.1\end{array}$ & $\begin{array}{l}4.5- \\
5.3\end{array}$ & $\begin{array}{l}14.8 \\
- \\
21.4\end{array}$ & $\begin{array}{l}3.4-4.6 \\
\text { calc }\end{array}$ & $18-19$ & $45-47 / 21$ & $\begin{array}{l}413-568(10- \\
19.6 \text { calc })\end{array}$ & present & S-shaped & present (3.9-4.6) \\
\hline
\end{tabular}




\begin{tabular}{|c|c|c|c|c|c|c|c|c|c|c|c|}
\hline $\begin{array}{l}\text { Enoploides disparilis } \\
\text { Sergeeva, 1974* }\end{array}$ & 2250 & 44.7 & 4.4 & 9.8 & $\begin{array}{l}\text { not } \\
\text { measur } \\
\text { ed }\end{array}$ & 12.5 & not measured & $35(0.9)$ & present (19) & Small & absent \\
\hline $\begin{array}{l}\text { Enoploides fluviatilis } \\
\text { Micoletzky, 1923* }\end{array}$ & $\begin{array}{l}1340- \\
1900\end{array}$ & $\begin{array}{l}42.5- \\
53\end{array}$ & $\begin{array}{l}2.4- \\
3.23\end{array}$ & $\begin{array}{l}25- \\
31\end{array}$ & $\begin{array}{l}\text { not } \\
\text { measur } \\
\text { ed }\end{array}$ & $8.5-10$ & $24-27 / 10$ & $(1.46-1.84)$ & present & Unclear & present (2) \\
\hline $\begin{array}{l}\text { Enoploides gryphus Wieser } \\
\text { \& Hopper, } 1967\end{array}$ & $\begin{array}{l}3000- \\
3700\end{array}$ & & $\begin{array}{l}\sim 3.7 \\
-4.1 \\
\text { calc }\end{array}$ & $\begin{array}{l}\sim 15 \\
\text { calc }\end{array}$ & $\sim 4$ calc & $28-32$ & $60-80 / 20-27$ & $\begin{array}{l}230-260 \\
(\sim 4.3-5.1 \\
\text { calc })\end{array}$ & present & S-shaped & $\begin{array}{l}\text { present } 80-110(\sim 1.8 \\
\text { calc) }\end{array}$ \\
\hline $\begin{array}{l}\text { Enoploides harpax Wieser, } \\
1959\end{array}$ & 4150 & 50 & 4.4 & 27.7 & $3.5-4$ & 25 & $62 / 28$ & $290(5.8$ calc $)$ & present & $\begin{array}{l}\text { S-shaped, with two } \\
\text { hooks }\end{array}$ & present $120(2.4$ calc $)$ \\
\hline $\begin{array}{l}\text { Enoploides hirsutus } \\
\text { Filipjev, } 1918\end{array}$ & 2850 & 24 & 3.8 & 19 & $\begin{array}{l}\text { not } \\
\text { measur } \\
\text { ed }\end{array}$ & 8 & $27 / 23$ & $425(8.3)$ & present (43) & $\begin{array}{l}\text { Unpaired, flat } \\
\text { triangular }\end{array}$ & present (3) \\
\hline $\begin{array}{l}\text { Enoploides incurvatus } \\
\text { (Ditlevsen, 1926) } \\
\text { Greenslade \& Nicholas, } \\
1991\end{array}$ & 4300 & 30 & 5 & 18.7 & $\begin{array}{l}\text { not } \\
\text { measur } \\
\text { ed }\end{array}$ & $\begin{array}{l}\text { not } \\
\text { measured }\end{array}$ & not measured & $\begin{array}{l}176 \\
\text { *measured in } \\
\text { linear }\end{array}$ & $\begin{array}{l}\text { uncertain } \\
\text { "small" }\end{array}$ & Small & present 160 \\
\hline $\begin{array}{l}\text { Enoploides labiatus } \\
\text { (Bütschli, 1874) Filipjev, } \\
1918\end{array}$ & $\begin{array}{l}2800- \\
3700\end{array}$ & $22-29$ & $\begin{array}{l}4.1- \\
4.7\end{array}$ & $\begin{array}{l}17- \\
20.5\end{array}$ & $\begin{array}{l}\text { not } \\
\text { measur } \\
\text { ed }\end{array}$ & $\begin{array}{l}0.25 \text { head } \\
\text { diameter }\end{array}$ & $\begin{array}{l}1 \text { head } \\
\text { diameter/0.5- } \\
0.6 \text { head } \\
\text { diameter }\end{array}$ & $\begin{array}{l}300-330 \\
(5.0-5.9)\end{array}$ & present (1 abd) & $\begin{array}{l}\text { Complex with } \\
\text { multiple parts }\end{array}$ & present (3) \\
\hline $\begin{array}{l}\text { Enoploides labrostriatus } \\
\text { (Southern, 1914) Filipjev, } \\
1921\end{array}$ & 5550 & 42 & 6.85 & 20 & $\begin{array}{l}4.6 \\
\text { calc }\end{array}$ & $\begin{array}{l}\text { not } \\
\text { measured }\end{array}$ & not measured & 490 (8.1 calc) & present & S-shaped "tubular" & present $(\sim 2.3$ calc $)$ \\
\hline $\begin{array}{l}\text { Enoploides longispiculosus } \\
\text { Vitiello, } 1967\end{array}$ & $\begin{array}{l}3700- \\
4055\end{array}$ & $\begin{array}{l}20.9- \\
22.1\end{array}$ & 4.4 & $\begin{array}{l}17.6 \\
- \\
19.4\end{array}$ & $\begin{array}{l}\text { not } \\
\text { measur } \\
\text { ed }\end{array}$ & $15-18$ & $51-64 / 42-43$ & $460(5.4)$ & present (74) & $\begin{array}{l}\text { Complex, massive, } \\
\text { strongly } \\
\text { cuticularized with } \\
\text { multiple parts }\end{array}$ & present 233 (2.7) \\
\hline $\begin{array}{l}\text { Enoploides mandibularis } \\
\text { Coles, } 1977\end{array}$ & $\begin{array}{l}4800- \\
6400\end{array}$ & $\begin{array}{l}\sim 24- \\
26.6 \\
\text { calc }\end{array}$ & $\begin{array}{l}\sim 4.8 \\
-5.8 \\
\text { calc }\end{array}$ & $\begin{array}{l}\sim 15- \\
16 \\
\text { calc }\end{array}$ & $\begin{array}{l}\sim 3.5-4 \\
\text { calc }\end{array}$ & 10 & $30 / 20$ & $\begin{array}{l}400-460 \\
(\sim 4.4-4.6 \\
\text { calc })\end{array}$ & present & $\begin{array}{l}\text { "short, weakly } \\
\text { developed" }\end{array}$ & present 350 \\
\hline
\end{tabular}




\begin{tabular}{|c|c|c|c|c|c|c|c|c|c|c|c|}
\hline $\begin{array}{l}\text { Enoploides polysetosus } \\
\text { Jensen, } 1986\end{array}$ & $\begin{array}{l}4380- \\
5160\end{array}$ & $41-60$ & $\begin{array}{l}3.8- \\
4.5\end{array}$ & $\begin{array}{l}11.7 \\
- \\
15.8\end{array}$ & $\begin{array}{l}5.4 \\
\text { calc }\end{array}$ & 20 & $45-50 / 28-30$ & $\begin{array}{l}162-174 \\
(\sim 2.8 \text { calc })\end{array}$ & present & $\begin{array}{l}\text { S-shape with two } \\
\text { teeth }\end{array}$ & $\begin{array}{l}\text { present } 132-158(\sim 2.3 \\
\text { calc) }\end{array}$ \\
\hline $\begin{array}{l}\text { Enoploides ponticus } \\
\text { Sergeeva, } 1974\end{array}$ & 3345 & 21.3 & 3.4 & 19.3 & $\begin{array}{l}2.7 \\
\text { calc }\end{array}$ & 21 & 23 & $343-363$ & present (54) & $\begin{array}{l}\text { Arcuate, consist of } \\
\text { two parts: distal } \\
\text { wide and proximal } \\
\text { narrow/curved }\end{array}$ & present $175(2.7)$ \\
\hline $\begin{array}{l}\text { Enoploides rimiformis } \\
\text { Pavljuk, } 1984\end{array}$ & $\begin{array}{l}2200- \\
2300\end{array}$ & $44-55$ & $\begin{array}{l}4.6- \\
5\end{array}$ & $\begin{array}{l}19- \\
20.3\end{array}$ & & 20 & $43 / 21$ & $188-192(\sim 7)$ & present (33) & $\begin{array}{l}\text { S-shaped with } 2 \\
\text { hooks }\end{array}$ & present 75 (3) \\
\hline $\begin{array}{l}\text { Enoploides spiculohamatus } \\
\text { Schulz, } 1932\end{array}$ & $\begin{array}{l}2340- \\
3030\end{array}$ & $\begin{array}{l}28.2- \\
34.3 \\
\text { calc }\end{array}$ & $\begin{array}{l}4.1- \\
4.6 \\
\text { calc }\end{array}$ & $\begin{array}{l}15.1 \\
- \\
15.9\end{array}$ & $2.7-3$ & 20 & $48 / 24-25$ & $280-356$ & present $(42-45)$ & $\begin{array}{l}\text { Complex structure } \\
\text { with multiple parts; } \\
\text { pair of plates joined } \\
\text { by process at } \\
\text { proximal end, distal } \\
\text { end grooved with } \\
\text { claw-shaped } \\
\text { projection on dorsal } \\
\text { groove, two rounded } \\
\text { projections in } \\
\text { ventrolateral } \\
\text { position. }\end{array}$ & $\begin{array}{l}\text { present } 89-94(1.5-1.7 \\
\text { calc) }\end{array}$ \\
\hline $\begin{array}{l}\text { Enoploides stewarti } \\
\text { Nicholas, 1993* }\end{array}$ & $\begin{array}{l}1930- \\
3080\end{array}$ & $28-49$ & $\begin{array}{l}3.9- \\
4.9\end{array}$ & $\begin{array}{l}17- \\
24\end{array}$ & $\begin{array}{l}1.7-2.7 \\
\text { calc }\end{array}$ & $8-15$ & $27-37 / 14-19$ & $\begin{array}{l}107-121 \\
(2.1-2.6)\end{array}$ & present & $\begin{array}{l}\text { Simple plate with } \\
\text { very weak apophysis }\end{array}$ & $\begin{array}{l}\text { present } 78-118(1.5- \\
2.4 \text { calc })\end{array}$ \\
\hline $\begin{array}{l}\text { Enoploides typicus } \\
\text { Ssaweljev, } 1912\end{array}$ & 2600 & 40 & 4.6 & 14 & $\begin{array}{l}\text { not } \\
\text { measur } \\
\text { ed }\end{array}$ & $\begin{array}{l}\text { not } \\
\text { measured }\end{array}$ & 8.2 & not measured & present & $\begin{array}{l}\text { Similar to } \\
\text { Mesacanthion } \\
\text { tenuicaudatus } \\
\text { "median plate with } \\
\text { two lateral grooves } \\
\text { with loops" }\end{array}$ & unclear \\
\hline $\begin{array}{l}\text { Enoploides tyrrhenicus } \\
\text { Brunetti, 1949* }\end{array}$ & $\begin{array}{l}1776- \\
2044\end{array}$ & $30-40$ & $\begin{array}{l}3.3- \\
3.6\end{array}$ & $\begin{array}{l}12.2 \\
- \\
16.3\end{array}$ & & 24 & $70-75 / 30$ & $87-90$ & present & "Complicated" & absent \\
\hline $\begin{array}{l}\text { Enoploides vectis Gerlach, } \\
1957\end{array}$ & 3160 & 50 & 4.2 & 15.8 & $\begin{array}{l}3.8 \\
\text { calc }\end{array}$ & 27 & $64 / 20$ & 340 & present (57) & $\begin{array}{l}\text { Complex with bent } \\
\text { projection at } \\
\text { proximal end }\end{array}$ & present $41(0.8)$ \\
\hline
\end{tabular}


Enoploides koreanus sp. nov.*
$3.7-4.2 \quad 11-18$

$30-43 / 11-18$
34-39 (1.1-

1.3)
Rod-like plate with round head on distal present 82-87

2 Table 2. Comparison of diagnostic morphological characters of all Enoploides species. Males only, morphometric values are rounded. 3 Species with spicules shorter than $150 \mu \mathrm{m}$ are marked with asterisk. 


\section{Table 3(on next page)}

Comparison of diagnostic morphological characters between Epacanthion hirsutum found from Korea and from original description.

Males only, morphometric values rounded. 
1

\begin{tabular}{|c|c|c|}
\hline Characters & $\begin{array}{c}\widehat{\partial}(\mathrm{n}=1) \\
\text { from Jeju Island, } \\
\text { Korea }\end{array}$ & $\begin{array}{c}\hat{\jmath}(\mathrm{n}=10) \\
\text { from original description } \\
(\text { Shi \& Xu, 2016) }\end{array}$ \\
\hline body length & 2468 & $1879-2433$ \\
\hline length of inner labial setae & 15 & $13-20$ \\
\hline length of outer labial setae & 35 & $30-35$ \\
\hline length of cephalic setae & 19 & $12-14$ \\
\hline mandible length & 18 & $13-17$ \\
\hline mandible length to width, ratio & 2 & $1.7-2$ \\
\hline tooth length & 8 & $7-10$ \\
\hline distance from nerve ring from anterior end & 145 & $133-145$ \\
\hline pharynx (oesophagus) length & 723 & $625-700$ \\
\hline tail length & 183 & $167-198$ \\
\hline anal body diameter & 41 & $39-43$ \\
\hline spicule length as arc & 30 & $21-33$ \\
\hline spicule length as arc / anal body diameter & 1 & $0.5-0.8$ \\
\hline length of gubernaculum & 6 & $5-9$ \\
\hline $\mathrm{a}$ & 49.4 & $37.6-52.1$ \\
\hline $\mathrm{b}$ & 3.4 & $2.9-3.5$ \\
\hline $\mathrm{c}$ & 13.5 & $10-13.7$ \\
\hline$c^{\prime}$ & 4.5 & $4.1-5$ \\
\hline
\end{tabular}

2

3 Table 3. Comparison of diagnostic morphological characters between Epacanthion hirsutum

4 found from Korea and from original description. Males only, morphometric values are rounded. 
Table 4 (on next page)

Kimura 2-parameter distance between six Enoploides species from Jeju Island based on COI alignment. 
1

Enoploides koreanus [MN514234]

Enoploides koreanus [MN514235]

Enoploides koreanus [MN514236]

0.000

Enoploides koreanus [MN514237]

$\begin{array}{ll}0.000 & 0.000\end{array}$

$\begin{array}{lll}0.000 & 0.000 & 0.000\end{array}$

Enoploides sp. [HM564984]

$\begin{array}{llll}0.191 & 0.191 & 0.191 & 0.191\end{array}$

Enoploides sp. [HM64945]

$\begin{array}{lllll}0.236 & 0.236 & 0.236 & 0.236 & 0.218\end{array}$

Enoploides longispiculosus [FN998930]

$\begin{array}{lllll}0.225 & 0.225 & 0.225 & 0.225 & 0.204\end{array}$

2

3 Table 4. Kimura 2-parameter distance between all available sequences of Enoploides species 4 based on mtCOI alignment.

5 


\section{Table 5 (on next page)}

Sequences retrieved from GenBank for phylogenetic analysis of this study. 


\begin{tabular}{|c|c|c|c|c|}
\hline Name & Family & Marker & $\begin{array}{l}\text { Accession } \\
\text { number }\end{array}$ & Reference \\
\hline Metoncholaimus sp. & Oncholaimidae & 18S rRNA & GU139748.1 & Pereira et al. (2010) \\
\hline Oncholaimus sp. & Oncholaimidae & 18S rRNA & GU139747.1 & Pereira et al. (2010) \\
\hline Viscosia sp. & Oncholaimidae & 18S rRNA & GU139749.1 & Pereira et al. (2010) \\
\hline Rhabdodemania sp. & Rhabdodemaniidae & 18S rRNA & GU139750.1 & Pereira et al. (2010) \\
\hline Enoploides koreanus & Thoracostomopsidae & 18S rRNA & MN512311 & This study \\
\hline Enoploides koreanus & Thoracostomopsidae & 18S rRNA & MN512312 & This study \\
\hline Enoploides koreanus & Thoracostomopsidae & 18S rRNA & MN512313 & This study \\
\hline Enoploides koreanus & Thoracostomopsidae & 18S rRNA & MN512314 & This study \\
\hline Enoploides koreanus & Thoracostomopsidae & $\mathrm{mtCOI}$ & MN514234 & This study \\
\hline Enoploides koreanus & Thoracostomopsidae & $\mathrm{mtCOI}$ & MN514235 & This study \\
\hline Enoploides koreanus & Thoracostomopsidae & $\mathrm{mtCOI}$ & MN514236 & This study \\
\hline Enoploides koreanus & Thoracostomopsidae & $\mathrm{mtCOI}$ & MN514237 & This study \\
\hline Enoploides longispiculosus & Thoracostomopsidae & $\mathrm{mtCOI}$ & FN998930 & Derycke et al. 2010 \\
\hline Enoploides sp. & Thoracostomopsidae & 18S rRNA & GU139765.1 & Pereira et al. (2010) \\
\hline Enoploides sp. & Thoracostomopsidae & $\mathrm{mtCOI}$ & HM564984 & Bik et al. (2010) \\
\hline Enoploides sp. & Thoracostomopsidae & $\mathrm{mtCOI}$ & HM564945 & Bik et al. (2010) \\
\hline Epacanthion hirsutum & Thoracostomopsidae & 18S rRNA & MN512317 & This study \\
\hline Epacanthion hirsutum & Thoracostomopsidae & 18S rRNA & MN512318 & This study \\
\hline Epacanthion hirsutum & Thoracostomopsidae & 18S rRNA & MG599065 & $\begin{array}{l}\text { Shi, Pu \& Xu, 2017, } \\
\text { unpublished data }\end{array}$ \\
\hline Epacanthion hirsutum & Thoracostomopsidae & $\mathrm{mtCOI}$ & MN514241 & This study \\
\hline Epacanthion hirsutum & Thoracostomopsidae & $\mathrm{mtCOI}$ & MN514242 & This study \\
\hline Epacanthion sp. & Thoracostomopsidae & 18S rRNA & GU139759.1 & Pereira et al. (2010) \\
\hline Mesacanthion sp. 1 & Thoracostomopsidae & 18S rRNA & GU139757.1 & Pereira et al. (2010) \\
\hline Mesacanthion sp. 2 & Thoracostomopsidae & 18S rRNA & GU139756.1 & Pereira et al. (2010) \\
\hline Mesacanthion sp. 3 & Thoracostomopsidae & $18 \mathrm{~S}$ rRNA & GU139758.1 & Pereira et al. (2010) \\
\hline Bathylaimus sp. & Tripyloididae & 18S rRNA & GU139751.1 & Pereira et al. (2010) \\
\hline
\end{tabular}

1

2

3 Table 5. Sequences retrieved from GenBank for phylogenetic analysis of this study. 